\title{
The Eemian stratotype locality at Amersfoort in the central Netherlands: a re-evaluation of old and new data
}

\author{
P. Cleveringa ${ }^{1,2}$, T. Meijer ${ }^{1}$, R.J.W. van Leeuwen ${ }^{1}$, H. de Wolf ${ }^{1}$, R. Pouwer ${ }^{1}$, \\ T. Lissenberg ${ }^{1} \&$ A.W. Burger ${ }^{1}$ \\ 1 Corresponding author; e-mail: p.cleveringa@nitg.tno.nl \\ 2 Netherlands Institute of Applied Geoscience TNO - National Geological \\ Survey, PO Box 80015, 3508 TA UTRECHT, the Netherlands
}

Received: May 2000; accepted in revised form: 6 June 2000

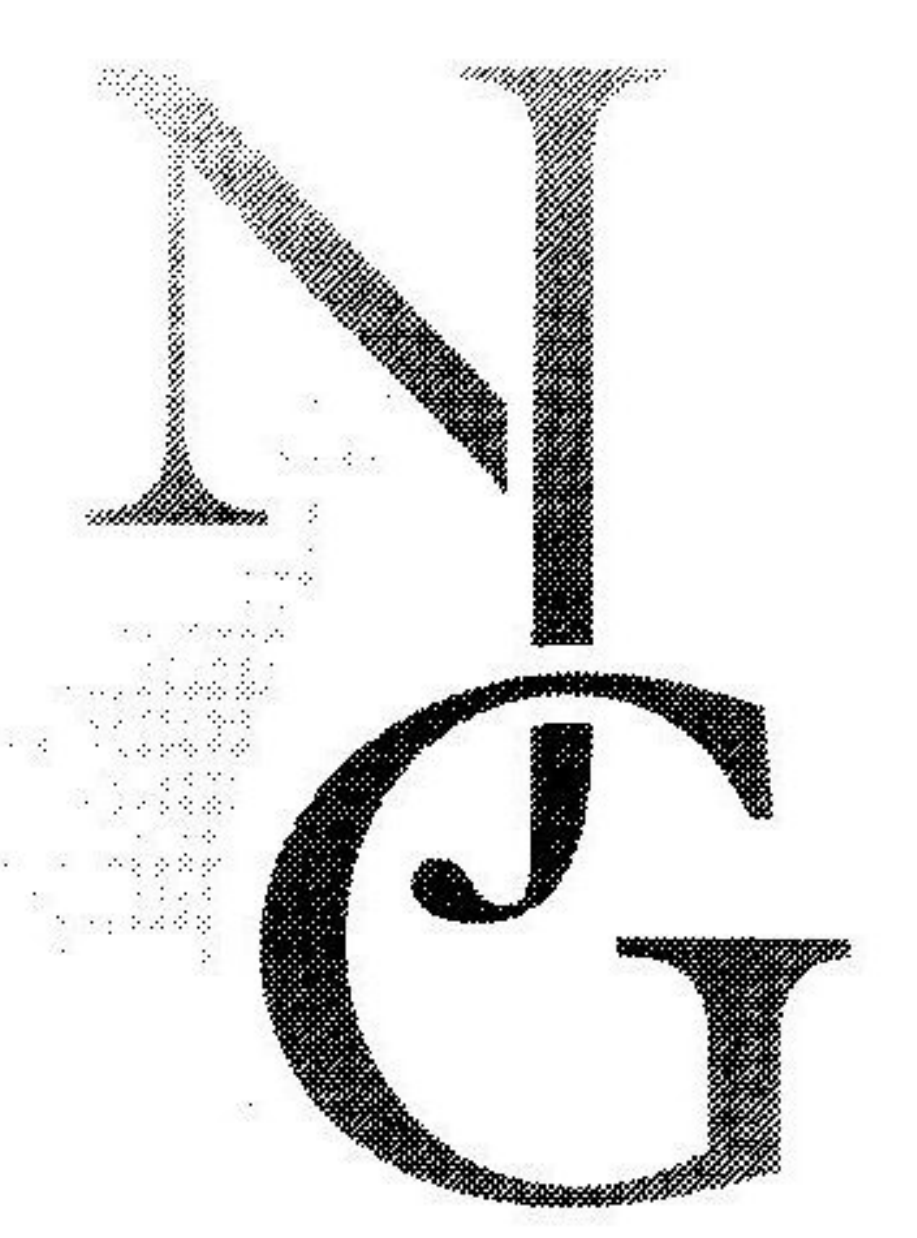

\begin{abstract}
In order to obtain a better understanding of the infilling of the Saalian glacial basins during the Eemian, particularly following the recent research in the Amsterdam Basin (Terminal borehole), it was necessary to re-investigate the type locality of the Eemian at Amersfoort. Both published and unpublished data from various biota (diatoms, foraminifers, molluscs, ostracods, pollen) provide new information on the changing sedimentary environments during the Eemian. Although the organic and clastic sediments of the infilling represent nearly all the pollen zones, the sedimentary sequence at Amersfoort is discontinuous: four breaks at least are recognised at the type locality.

The successive sedimentary environments and the breaks in the record are linked with the transgression of the Eemian sea, the topographic position at the margin of an ice-pushed ridge, and the changes in hydrodynamic conditions. Local conditions, such as a sandy sea bed, shallow water and a reduced water exchange near the North Sea margin, influenced the salinity of the basin. Rib counts of Cerastoderma edule shells indicate a higher salinity at the end of the Taxus (E4b) and the beginning of the Carpinus (E5) zones than that present in the modern North Sea. Local conditions were responsible for the higher salinity following the climate optimum.

During the Abies phase (the later part of regional pollen zone E5), the sea level had already fallen. The change from eutrophic peat growth (with Alnus and Salix) to an oligotrophic Ericaceae/Sphagnum community at the end of the Eemian resulted from the change from a marine to a fresh-water environment, probably coherent with a deterioration of the climate.
\end{abstract}

Keywords: biostratigraphy, climate, Eemian stratotype, fauna, flora, lithology, palaeoenvironment, sea level

\section{Introduction}

In 1961, Zagwijn investigated the palynology of the Eemian deposits in two boreholes drilled close to the town of Amersfoort (Fig.1) and proposed them as the stratotype of the Eemian stage in the Netherlands. With the progressing 1:50,000 geological mapping, the knowledge of the Saalian glaciation - more precisely the presence of deep glacial basins and their infilling during the Eemian - increased (Jelgersma \& Breeuwer, 1975).

Later investigations by Zagwijn (1983) demonstrated that boreholes from the Amsterdam Basin (Fig. 2) showed a more continuous sedimentary and biostratigraphical record of the Eemian. Since an even more complete record of the stage became available in 1997 from the 'Terminal borehole' in the Amsterdam Basin (Van Leeuwen et al., 2000 - this issue) it was considered necessary to re-evaluate the pollen and foraminifer-content of the type locality at Amersfoort. It was also necessary to supplement these analyses with old and new data on the diatom, foraminiferan, mollusc, ostracod and pollen evidence. This was also supplemented with some information on the heavymineral content of the sedimentary filling of the Amersfoort Basin. 


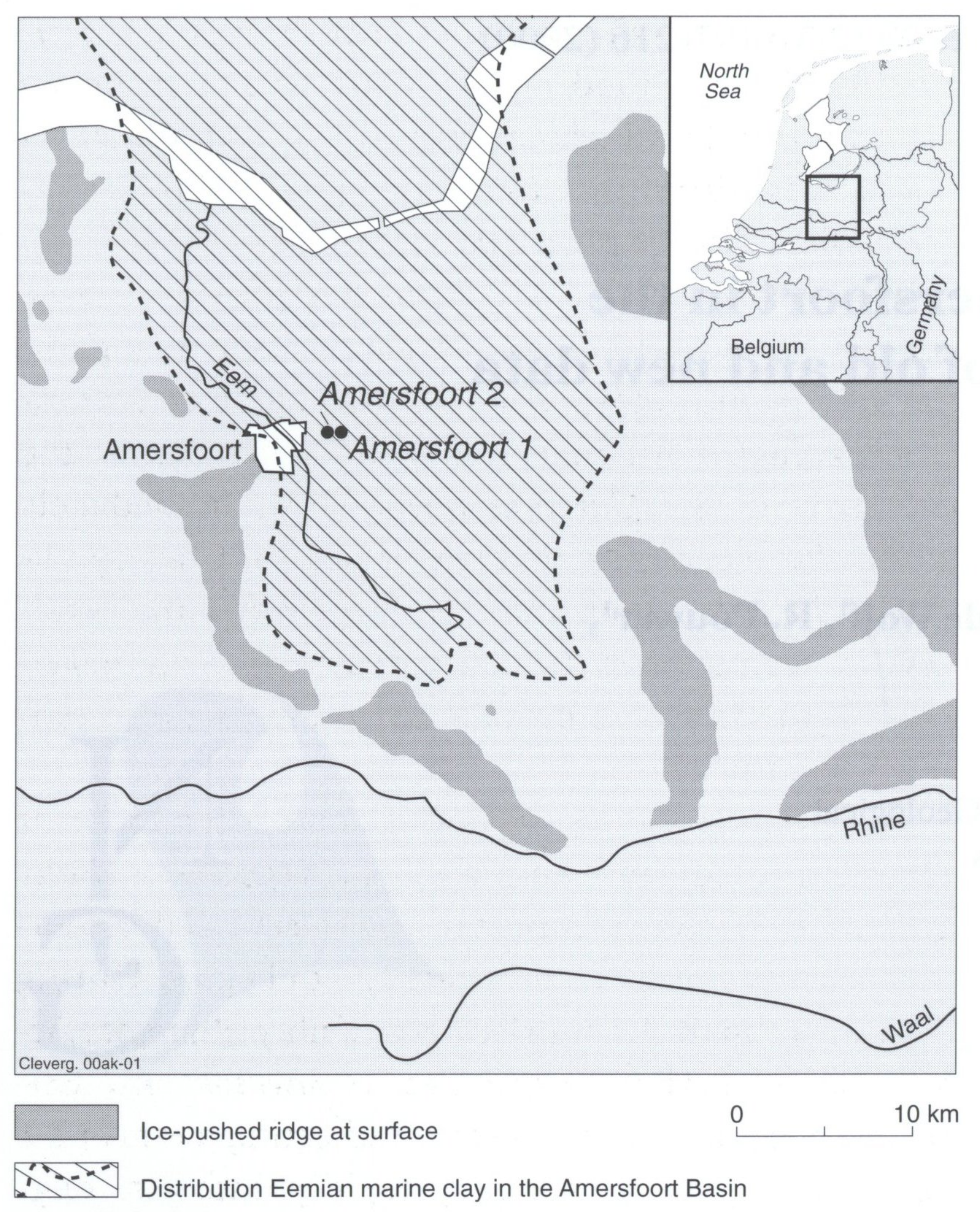

Fig. 1. The Amersfoort Basin and the location of boreholes Amersfoort-1 and Amersfoort-2.

\section{Geological setting}

Eemian-stage sediments are common in the subsoil of the western and northern Netherlands, where they were deposited in depressions of the glacier-moulded landscape over which the Eemian sea transgressed. Because of the slow but continuous tectonic subsidence of this region, these deposits have been preserved below the surface, at depths between approx. 10 and $80 \mathrm{~m}$ below NAP (Dutch Ordnance Level = mean sea level).

The Saalian (marine isotope stage 6: MIS 6) ice cap, which reached as far as the central Netherlands, excavated deep basins surrounded by ridges of icepushed sediments. These basins are filled by Saalian lacustrine sediments overlain by Eemian sediments of varying thickness, locally reaching over $50 \mathrm{~m}$. Two boreholes (Fig. 1), which were proposed as the stratotype locality, were put down at the margin of the Amersfoort Basin. This is the most central of the glacial basins (Fig. 2).

The Amersfoort Basin is bounded on its western, eastern and southern side by ice-pushed ridges. The development of the Eemian succession in the basin is basically similar to that of the Amsterdam Basin (De Gans et al., 2000 - this issue), both basins being separated from the open sea by sills at depths of about $-40 \mathrm{~m}$ NAP. The rising sea flooded the basins through

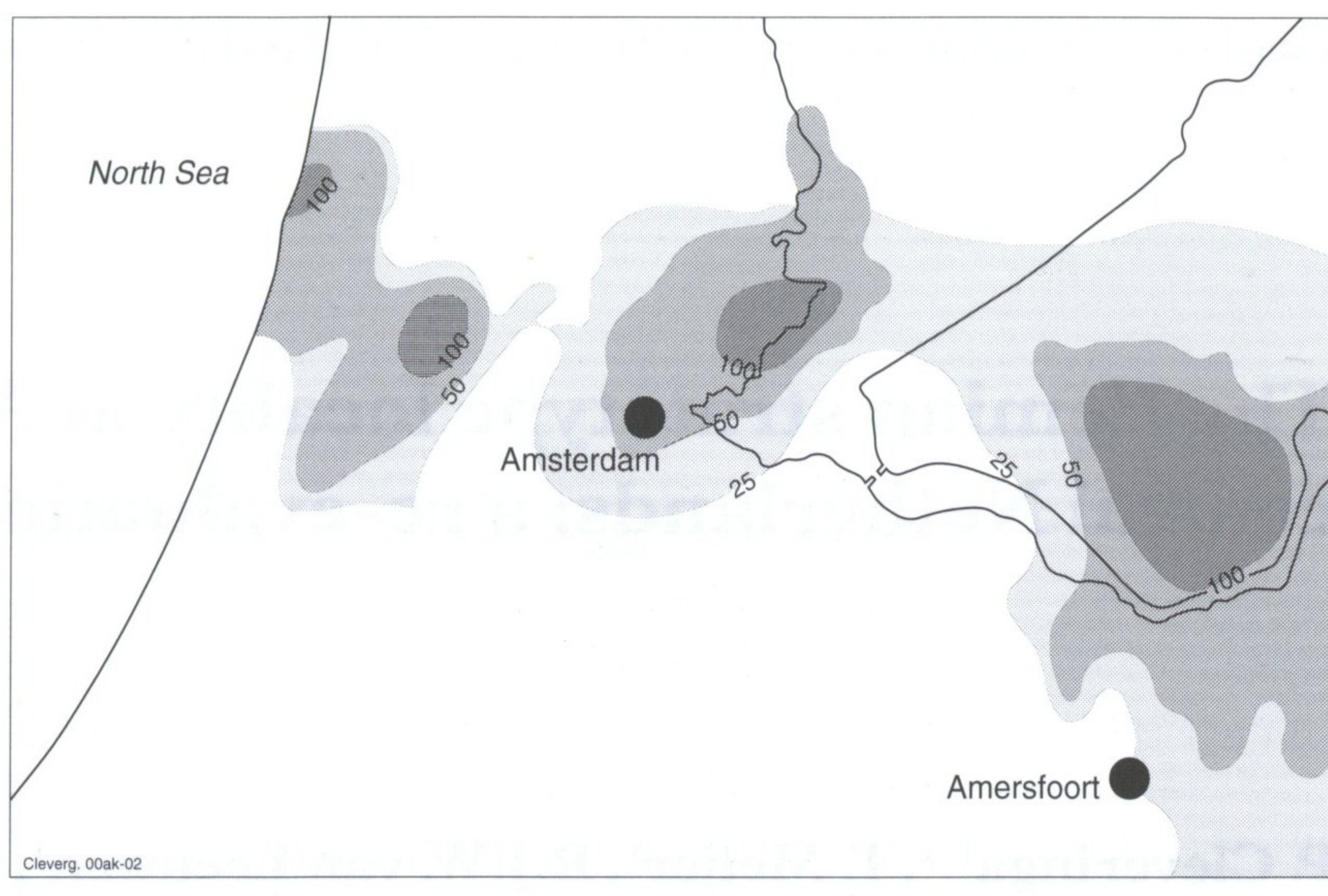

Fig. 2. The position of the Amersfoort Basin and the Amsterdam Basin in the Netherlands.

a deeply incised palaeovalley north of the sill. In the deeper part of the basin, south of the sill, a lake formed as a consequence of the rising groundwater table. After the sea level exceeded the height of the sill, the lake evolved gradually into a lagoon. At that moment, the site of the Amersfoort-1 borehole, at a depth of $-25 \mathrm{~m} \mathrm{NAP}$, was still above sea level. Because of the sill, the initial marine Eemian sediments were invariably fine-grained clays and mud. As the sea level rose and the water depth above the sill increased, wave energy became more and more important, however, although the sediments were still fine-grained clays. Only at the margins and in front of the expanding lagoon, could beaches and spits be formed.

\section{Results}

\section{Lithology}

The lithology of the Eemian sediments in the Amersfoort-1 and Amersfoort-2 boreholes represents the shallow-marine, marginal facies and thus deviates considerably from the sediments recorded in the central part of the Amersfoort Basin (Zagwijn, 1961; de Gans et al., 1987). As in the Amsterdam Basin (De Gans et al., 2000 - this issue), the sediments in the central part of the Amersfoort Basin consist of clays (at least $30-40 \mathrm{~m}$ ) overlain by about $25 \mathrm{~m}$ of marine sands. In the Amersfoort-1 borehole, however, the total Eemian succession, in which seven lithological units are distinguished (Table 1), is about $15 \mathrm{~m}$ thick.

\section{Pollen}

The pollen zonation used in the present contribution is based on Jessen \& Milthers (1928), Zagwijn (1961) and Zagwijn \& Van Staalduinen (1975). A pollen diagram from the recounted Amersfoort-1 borehole, with a restricted number of curves, is shown in Figure 3 
Table 1. Lithological units of Eemian deposits in borehole Amersfoort-1 (borehole 32B119). Depths are indicated in meters below NAP (= Dutch Ordnance Level). L = lithological unit.

\begin{tabular}{llc}
\hline depth (m -NAP) & lithology & unit \\
\hline $25.01-24.44$ & $\begin{array}{l}\text { gyttja, rich in carbonate, with } \\
\text { freshwater molluscs }\end{array}$ & L1 \\
& $\begin{array}{l}\text { fine-grained organic-rich layer with } \\
\text { a brackish marine fauna }\end{array}$ & L2 \\
& $\begin{array}{l}\text { organic-rich sands } \\
\text { 23.95-23.68 }\end{array}$ & L3 \\
$23.68-22.60$ & $\begin{array}{l}\text { clay-rich sands with shells } \\
22.60-14.79\end{array}$ & L4 \\
$14.79-10.51$ & $\begin{array}{l}\text { clays and sandy clays with marine } \\
\text { shells, occasionally in living position }\end{array}$ & L6 \\
$10.51-09.90$ & $\begin{array}{l}\text { wood peat with some clays and silty } \\
\end{array}$ & peat intercalations \\
\end{tabular}

(Alnus is not shown); the figure shows also the pollen zonation and the lithology. A striking difference between this new diagram and the older one of Zagwijn (1961) is the presence of Taxus in the former (Taxus is a taxon that could not be identified until the late 1960s).

The pollen sequence in Amersfoort-1 begins in pollen zone E2, where the gyttja (unit L1) shows a dominance of Pinus. This gyttja development continues in pollen zone E3, which is (from 24.75-24.44 m) characterised by the presence of Quercus and $\mathrm{Ul}$ mus, whereas Corylus increases in the upper part of this zone.

The first marine influence, at $-24.44 \mathrm{~m}$ NAP (unit L2), is assigned to pollen zone E4a (maximum of Corylus). In the upper part of this zone, Taxus is already present at low percentages $(2-3 \%)$. At this point, the accumulation of organic matter is replaced by clastic sedimentation (unit L3). During pollen zone E4b (Taxus phase), Carpinus appears and is present at low percentages in the spectra from $23.85 \mathrm{~m}$. The normal Taxus maximum, in which this tree reaches relative high percentages before the arrival of Carpinus, is absent. The reason for this will be discussed below.

In the sandy sediments of unit L5, between -22.60 and $-14.79 \mathrm{~m}$, only one spectrum - containing very few pollen - could be counted. It was assigned to pollen zone $\mathrm{E} 4 \mathrm{~b}$ on the basis of the low percentage of Carpinus. The clay (unit L6) overlying the sandy sediments represents a part of pollen zone E5 (Carpinus phase). Because Abies and Picea are both present, the clay sedimentation can be assigned to the second part of pollen zone E5. During the main part of the Carpinus zone, sedimentation and resedimentation of locally eroded sandy material from surrounding icepushed ridges took place in the marginal zone of the Amersfoort Basin.
In boring Amersfoort-2, high percentages of Carpinus $(30 \%)$ are found in the sandy sediments below the clay (Fig. 4), which confirms this local sedimentation process during the Carpinus phase. This observation will be discussed below.

Between -13.30 and $-10.80 \mathrm{~m}$ NAP, trees decrease and are replaced by herbs, in particular Chenopodiaceae. This indicates a shift from a lagoonal environment to higher mudflats and saltmarshes during the later part of the Carpinus phase (E5). Immediately above, the spectra with high values of Chenopodiaceae, Alnus and then Salix reach their maximum values, indicating that the marine environment developed into one of eutrophic to mesotrophic freshwater conditions.

The boundary between pollen zones E5 and E6 at $-10.51 \mathrm{~m}$ is drawn where the local vegetation (Salix and Alnus) becomes important, the clastic sedimentation ceases (unit L7), and peat growth begins. During the peat growth the nutrient availability changed. After a short period Gramineae, Sphagnum and Ericaceae became important taxa, indicating a eutrophic peat development changing rapidly into an oligotrophic one. In this oligotrophic peat, only Pinus and Betula pollen were trapped. The replacement of the deciduous forests by a boreal arctic tree vegetation in pollen zone E6 is thus recorded. The cause of the relatively rapid transition from a brackish marine into a fresh-water environment will be discussed later.

\section{Molluscs}

Seventeen samples from the Amersfoort-1 borehole between -24.80 and $-10.90 \mathrm{~m}$ NAP (units L1-L6) have been investigated. Most of the shells encountered were very well preserved and are considered to have been in situ or only slightly displaced. A considerable part $(40-60 \%)$ of the assemblages consists of juvenile specimens. All assemblages are indicative of a temperate climate; the marine assemblages show high amounts of the lusitanian and mediterranean species already present in the first marine sample. Boreal or colder species are absent.

Six units (M1.1-M1.6) are distinguished (Fig. 5).

1 Unit M1.1 (-24.80 t0 -24.59 m) comprises a temperate fresh-water assemblage, indicating a shallow, quiet and well-vegetated lacustrine environment (Anodonta sp. indet., Bithynia tentaculata, Planorbis carinatus and Valvata piscinalis).

2 Unit M1.2 ( -24.28 to $-23.95 \mathrm{~m})$ is characterised by a marine assemblage of low diversity. It is dominated by Cerastoderma glaucum, which indicates very shallow sublittoral conditions with a small tidal amplitude and low salinity. Quiet and clear 


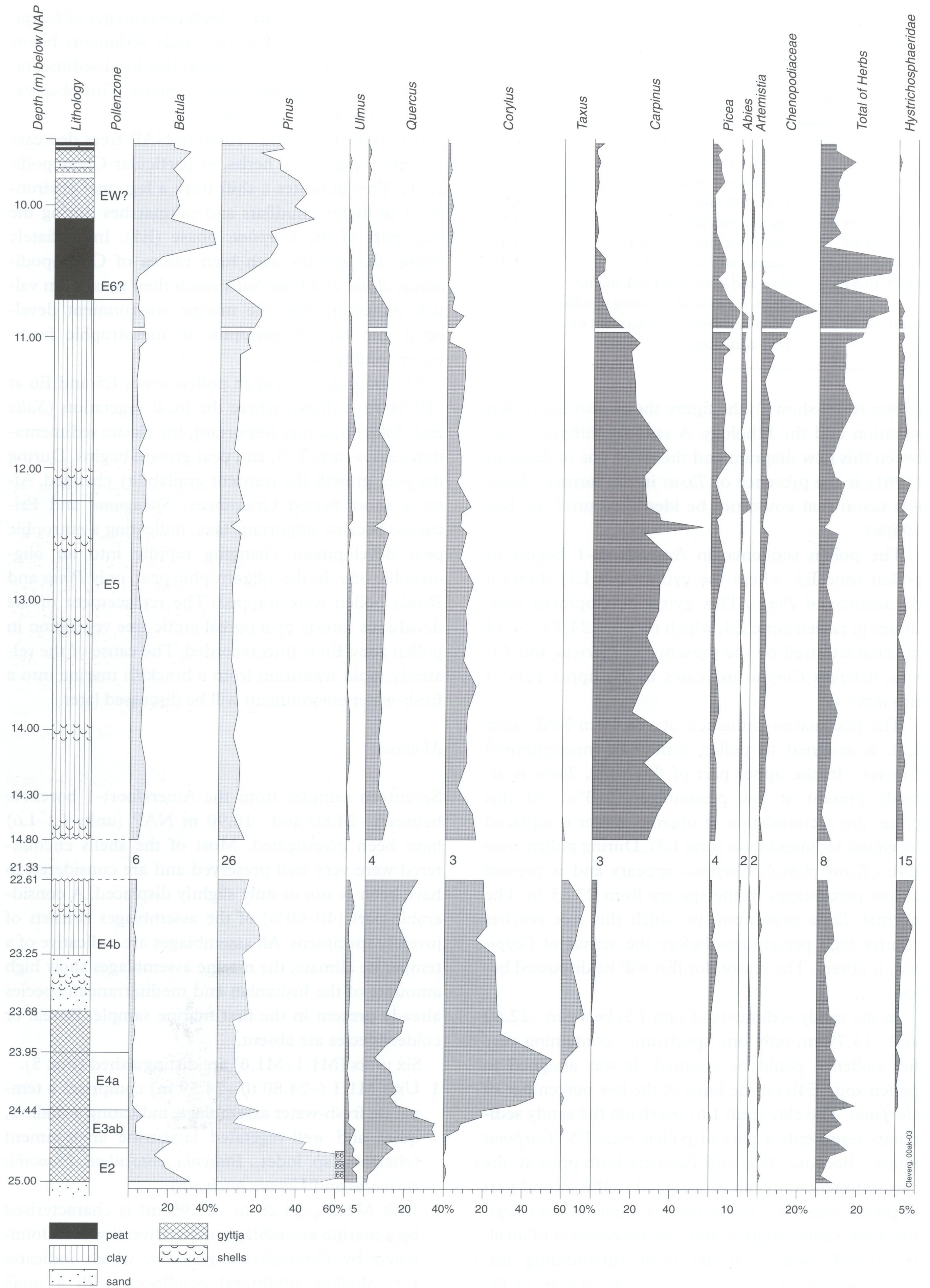

Fig. 3. Pollen diagram of the Amersfoort-1 borehole (selected species). 


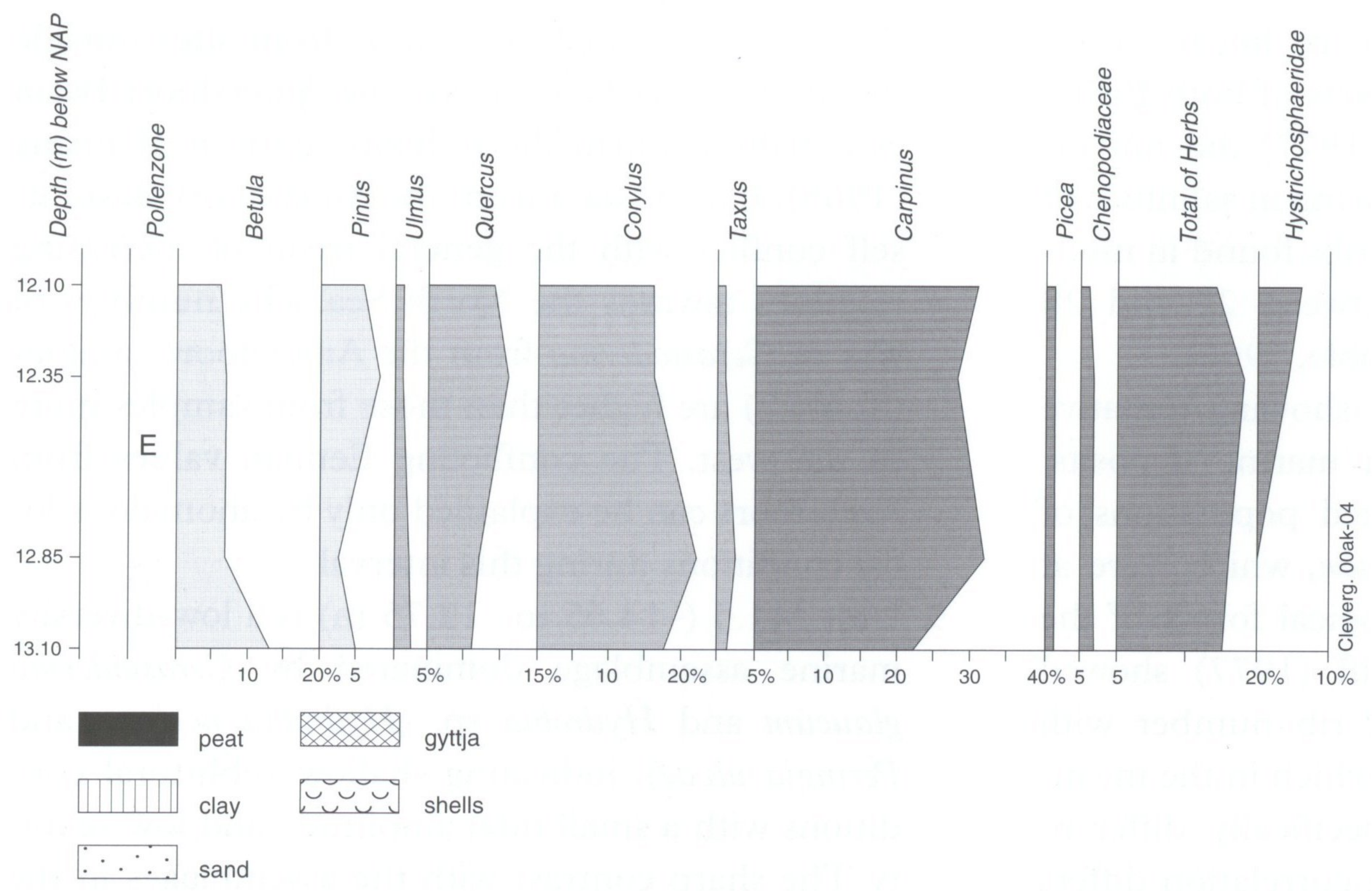

Fig. 4. Pollen diagram of the Amersfoort-2 borehole (selected species).

water with a vegetation of seaweed and/or Zostera occurred at the site.

3 Unit M1.3 ( -23.65 to $-19.80 \mathrm{~m}$ ) is represented by various marine assemblages. The most dominant species in all assemblages is Modiolus adriaticus. The molluscan faunas point to quiet sublittoral conditions with high salinity and a larger tidal amplitude than in unit M1.2.

A vegetation of seaweed and/or Zostera is indicated by the presence of, among other species, Bittium reticulatum, Rissoa labiosa, Turboella radiata balkei, Anisocycla nitidissima, Haminea navicula and Parvicardium exiguum. Remains of Zostera have been found at the transitional zone $(-21.80$ to $-18.80 \mathrm{~m}$ NAP) to unit M1.4. Towards the top of the unit, the water depth increased. The rather thin-walled shells of Cerastoderma edule in units M1.3 and
M1.4 indicate a submersed mode of life for this predominantly littoral species and do not necessarily point to nearby intertidal conditions.

4 Unit M1.4 ( -19.80 to $-14.85 \mathrm{~m}$ ) represents a highly divers marine assemblage dominated by Bittium reticulatum, which dominance indicates an increase in seaweed and/or Zostera vegetation. The boundary with unit M1.3 is arbitrary: both units show a similar species composition, but an increase in the abundance of several species is seen at the boundary. Besides this change, a remarkable increase in the number of ribs on the shells of Cerastoderma edule is present.

A linear correlation was found for this shell character with salinity: more ribs are present at higher salinities (Eisma, 1965; Koulman \& Wolff, 1977; Eisma et al., 1981). It is not certain whether the

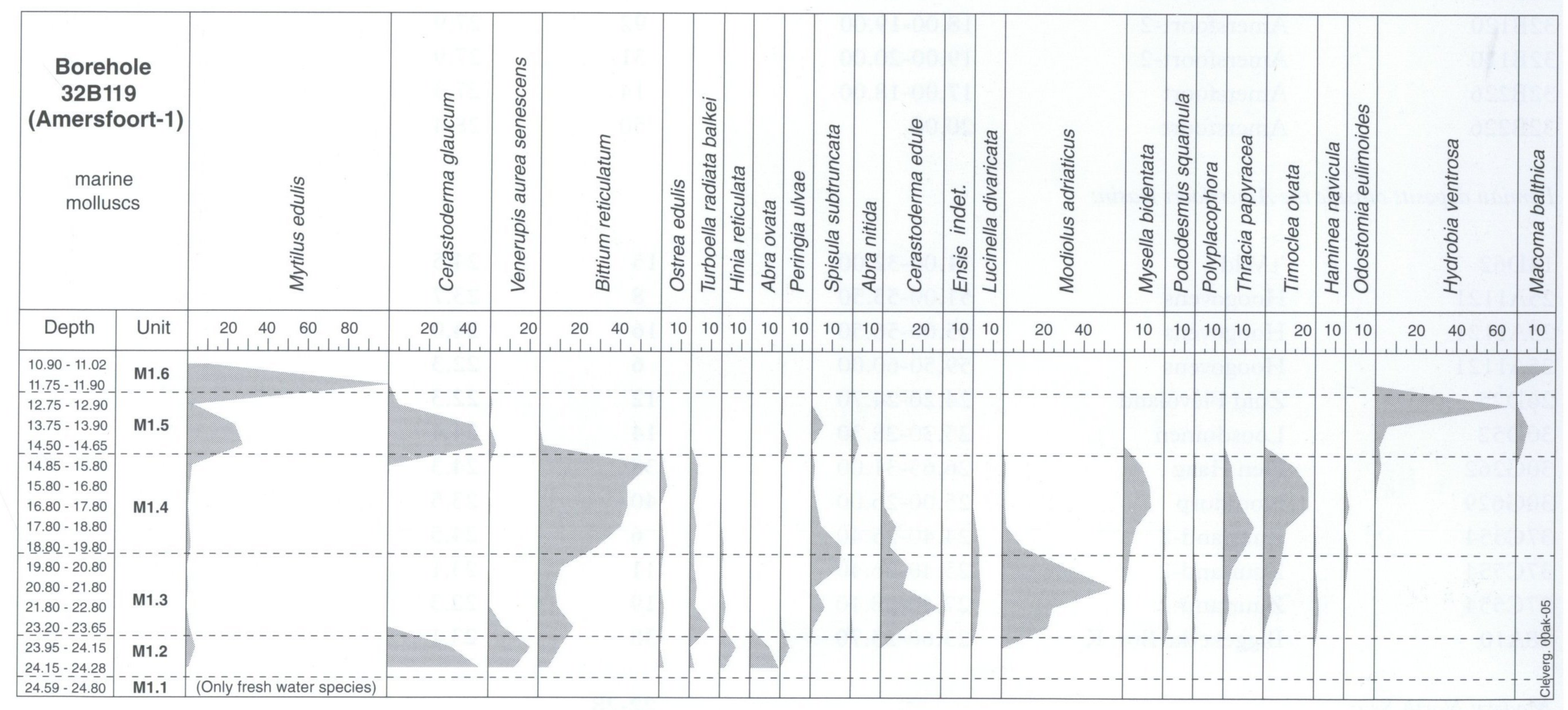

Fig. 5. Mollusc diagram of the Amersfoort-1 borehole (selected species) 
rib-number/salinity relationship is linear above these maxima because the data sets of both Eisma (1965) and Koulman \& Wolff (1977) did not include shells that exceed 24 ribs living in salinities of approx. $16.5 \%$. The number of ribs found in modern North Sea shells varies between 22 and 28 (Van Benthem Jutting, 1943; Tebble, 1966).

Eisma (1965) published a map showing tentative isohalines from Dutch Eemian marine deposits. His data were based upon mixed populations of Cerastoderma edule and C. glaucum, which were at the time considered to be ecological forms of the same species. Koulman \& Wolff (1977) showed that the positive correlation of rib number with salinity only applies to $C$. edule (which in the meantime was considered to be specifically different from $C$. glaucum). Their revised correlation differs only slightly from the older one, implying that the isohaline pattern of Eisma (1965) is essentially still correct. The isohalines show a general trend towards higher salinity values from the coastal zone into the North Sea. Data from the Amersfoort Basin were not available at the time.

Here new rib counts of Cerastoderma edule from Eemian deposits (Table 2), from the Amersfoort
Basin are presented, as well as from sites outside this basin. The data outside the Amersfoort Basin essentially confirm the isohaline pattern of Eisma (1965), but the data from the Amersfoort Basin itself conflict with the general trend of increasing salinities towards the North Sea. The numbers of ribs of Cerastoderma from the Amersfoort samples (Table 2) are higher than those from samples more to the west. The conflicting Eemian values from Amerfoort can be explained only by anomalous local conditions during this interval.

5 Unit M1.5 ( -14.65 to $-12.75 \mathrm{~m}$ ) is a low-diversity marine assemblage dominated by Cerastoderma glaucum and Hydrobia sp. (Hydrobia neglecta and Peringia ulvae), indicating shallow sublittoral conditions with a small tidal amplitude and low salinity. The sharp contrast with the assemblages in the underlying unit M1.4 is striking.

6 Unit $M 1.6$ ( -11.90 to $-10.90 \mathrm{~m}$ ) is a clay with few marine molluscs preserved. Deposition most probably took place in a high inter- to supratidal environment.

The molluscan assemblages of borehole Amersfoort1 (Fig. 6) show that the sequence begins as a shallow lacustrine environment and subsequently changes

Table 2. Rib numbers of shells of Cerastoderma edule from Dutch Eemian deposits and from the modern coast. Depths are indicated in meters below surface. $\mathrm{n}=$ sample size.

\begin{tabular}{lllrr}
\hline boring (code) & location/name & depth (m -NAP) & $\mathrm{n}$ & mean \\
\hline Eemian deposits inside the Amersfoort Basin: & & & \\
32A437 & Eemvalley KW223 & $9.80-12.00$ & 23 & 25.8 \\
32A437 & Eemvalley KW223 & $12.00-15.50$ & 27 & 27.3 \\
32B119 & Amersfoort-1 & $20.50-21.50$ & 60 & 27.9 \\
32B120 & Amersfoort-2 & $16.70-18.00$ & 100 & 27.6 \\
32B120 & Amersfoort-2 & $18.00-19.00$ & 92 & 27.9 \\
32B120 & Amersfoort-2 & $19.00-20.00$ & 31 & 27.9 \\
32B226 & Amersfoort & $17.00-18.00$ & 14 & 27.3 \\
32B226 & Amersfoort & 20.00 & 50 & 28.4
\end{tabular}

Eemian deposits outside the Amersfoort Basin:

$\begin{array}{lllrr}\text { 14D62 } & \text { 'tVeld } & 31.00-32.00 & 15 & 24.5 \\ \text { 25A1121 } & \text { Hoogovens } & 51.00-53.50 & 8 & 23.7 \\ \text { 25A1121 } & \text { Hoogovens } & 55.00-56.50 & 16 & 24.0 \\ \text { 25A1121 } & \text { Hoogovens } & 59.50-60.00 & 6 & 22.3 \\ \text { 26D25 } & \text { Zuid Flevoland } & 24.20-24.70 & 12 & 22.3 \\ \text { 30D52 } & \text { Loosduinen } & 25.30-28.30 & 14 & 24.4 \\ \text { 30G262 } & \text { Den Haag } & 26.65-31.00 & 38 & 24.3 \\ \text { 30G629 } & \text { Nootdorp } & 25.00-26.00 & 40 & 23.5 \\ \text { 37C554 } & \text { Zuurland-2 } & 24.40-25.40 & 6 & 24.5 \\ \text { 37C554 } & \text { Zuurland-2 } & 25.40-26.40 & 11 & 23.1 \\ \text { 37C554 } & \text { Zuurland-2 } & 27.40-28.40 & 19 & 22.3 \\ \text { 48A10 } & \text { Biggekerke Bor. K } & 23.60-25.70 & 38 & 23.1 \\ \text { Modern North Sea: } & & & & 22-28\end{array}$


from a brackish into a sheltered marine one. The greatest water depth was probably reached between -17.80 and $-16.80 \mathrm{~m}$ NAP. Several species suggest clear water, among them Ostrea edulis, the boring sponge, Cliona celata, and the mollusc species living on eelgrass (Zostera sp.) or seaweed. Remains of Zostera have been found in only a few samples. The epiphytic mollusc species encountered, however, indicate the general presence of eelgrass and/or seaweed vegetation. The marine molluscan assemblages all indicate lagoonal conditions. In the clay in the upper part of the sequence (unit L6), the molluscan assemblages and their preservation confirm an environmental change from a tidal marsh into a fresh-water environment.

The results of the molluscan analyses of borehole 32B120 (Amersfoort-2) are presented separately in Appendix 1 (see also Figs. 7 and 12), in which these results are compared with those of Amersfoort-1. A more sandy facies of the clay (unit L6) developed in Amersfoort-2 during pollen zone E5, when Abies pollen was virtually absent. The differences between Amersfoort- 1 and 2 are explained as sedimentation breaks due to local conditions. This is visualized in Figure 8. In Amersfoort-1, the clay sedimentation started during a later part of the Carpinus phase, when Abies shows a continuous curve; the sedimentary environment represents a tidal marsh. This change in environmental conditions is discussed below.

\section{Foraminifers}

Van Voorthuysen (1957) studied the foraminiferal faunas of the Amersfoort-1 borehole. To update his work, the original washed residues (fraction $>150$ $\mathrm{mm}$ ) were re-examined. Some sample material was still available and three additional subsamples were taken to fill gaps in the original data set. In his studies, Van Voorthuysen examined the unsplit wash residues, whereas a sodium-polytungstate solution is used nowadays to concentrate the foraminifers.

Species names have changed repeatedly since the study by Van Voorthuysen, but the taxonomy of the late Quaternary faunas of NW Europe is now stable. As a rule, we use the same names as Knudsen (1982, 1985). The one important exception is the classification of the morphologically complex group of Ammonia species, for which the nomenclature of Jorissen (1988) is used.

Most of the samples yielded sufficient foraminifers to allow an interpretation, but the uppermost $(-10.65$ to $-10.55 \mathrm{~m})$ and lowermost $(-25.01$ to $-24.46 \mathrm{~m})$ samples were barren. Apart from a few reworked planktics, only benthics were found. Most species are typical of the boreal faunal province and currently live in the North Sea, Wadden Sea and Baltic Sea. These areas provide the frame of reference for the environmental interpretation of the faunas. In addition, some lusitanian and mediterranean species (Elphidium translucens, E. lidoense and Quinqueloculina seminula jugosa) occurred. These are normal elements of the Eemian faunas of NW Europe and their presence is generally accepted as evidence for climatic conditions that are warmer than during the Holocene. The warm-water indicating species were not present at all levels in Amersfoort-1, but this is attributed to variation in environmental conditions rather than climate, as will be discussed later.

Four facies units (F1-F4) are identified (Fig. 9). A description at species level is given in Appendix 2. In the present section,only the derived environmental conditions are summarised.

The assemblage of unit F1 ( -24.41 to $-23.80 \mathrm{~m})$ is interpreted as indicating deposition at very shallow depth in waters with salinity well below normal marine values. To maintain such low salinities, a lagoonal environment is assumed. E. albiumbilicatum was absent in the uppermost sample, whereas Buccella frigi$d a$ was abundant. This fauna is considered to be transitional to the overlying unit, F2 $(-23.65$ to -17.80 $\mathrm{m})$. Unit $\mathrm{F} 2$ represents the deepening of the lagoon. Some influence from the inner shelf of the North Sea can be deduced from the preserved assemblage. The presence of Buccella frigida, together with lusitanian species like Elphidium translucens, is striking. The sands contained only a restricted foraminiferan assemblage in the upper part of the unit.

Unit F3 (-15.80 to $-12.15 \mathrm{~m}$ ) shows a shallowing of the water. The abundance of Ammonia parkinsoniana tepida, Elphidium gunteri and Nonion germanicus indicates the presence of mudflats in an estuarine environment. Unit F4 (-12.15 to $-10.65 \mathrm{~m})$ represents the same environment as unit F3. The dissolution of the foraminiferan tests, however, indicates a lowering of the water level, a prolonged period of non-deposition and non-flooding, and the beginning of soil processes.

\section{Diatoms}

Diatoms were found only between -24.44 and -20.80 $\mathrm{m}$ (units L2-L5) in the Amersfoort-I boring. In the lower part of the sequence, the diatoms were poorly preserved; even the very robust species are 'broken'. Dissolution of frustules, shortly after sedimentation, is probably responsible for the bad preservation and the absence of diatom fossils.

Six units were distinguished (Fig. 10). The flora is 


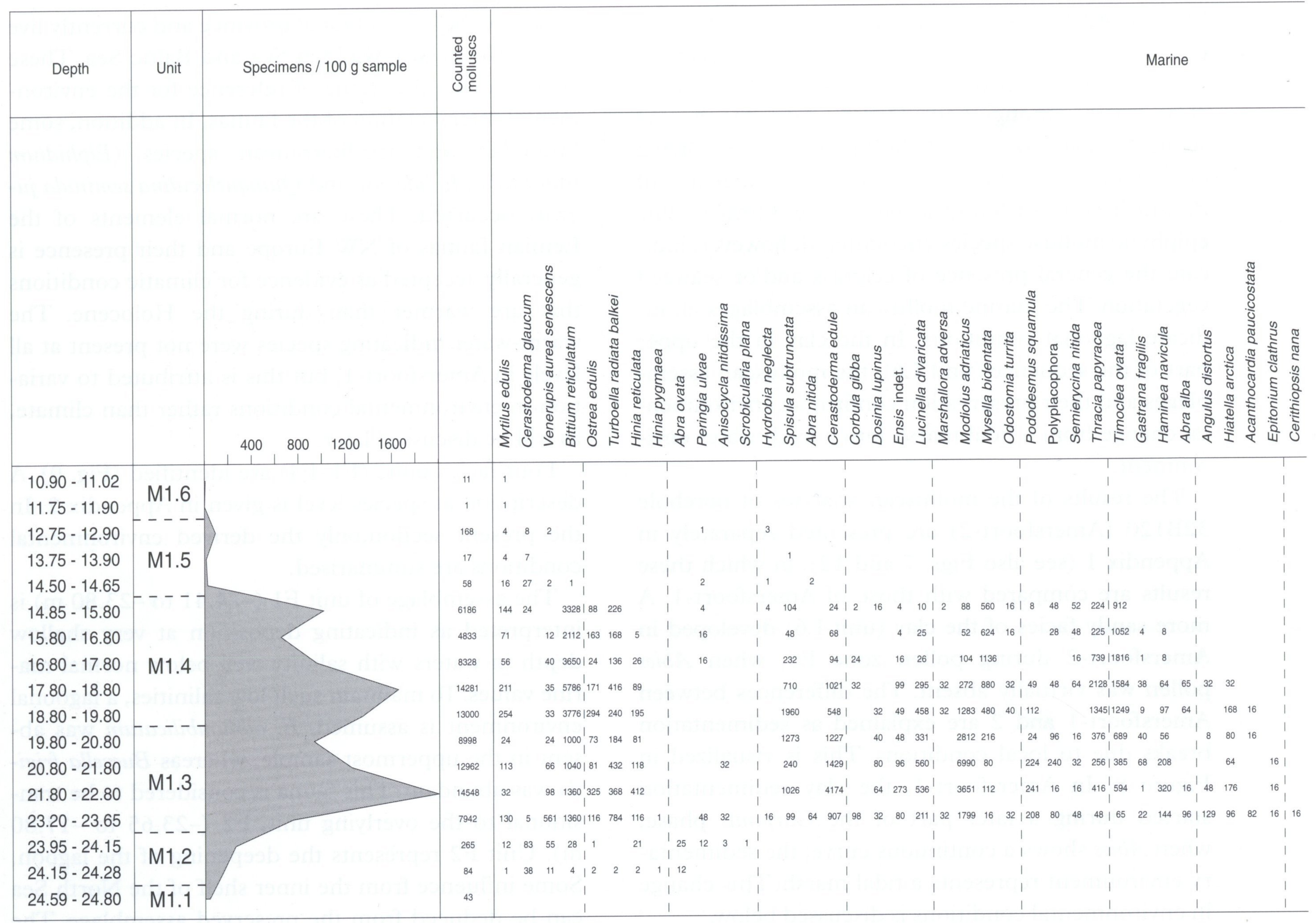

Fig. 6 (p. 204-205). Molluscs and other fossil groups in the Amersfoort-1 borehole (selected species).

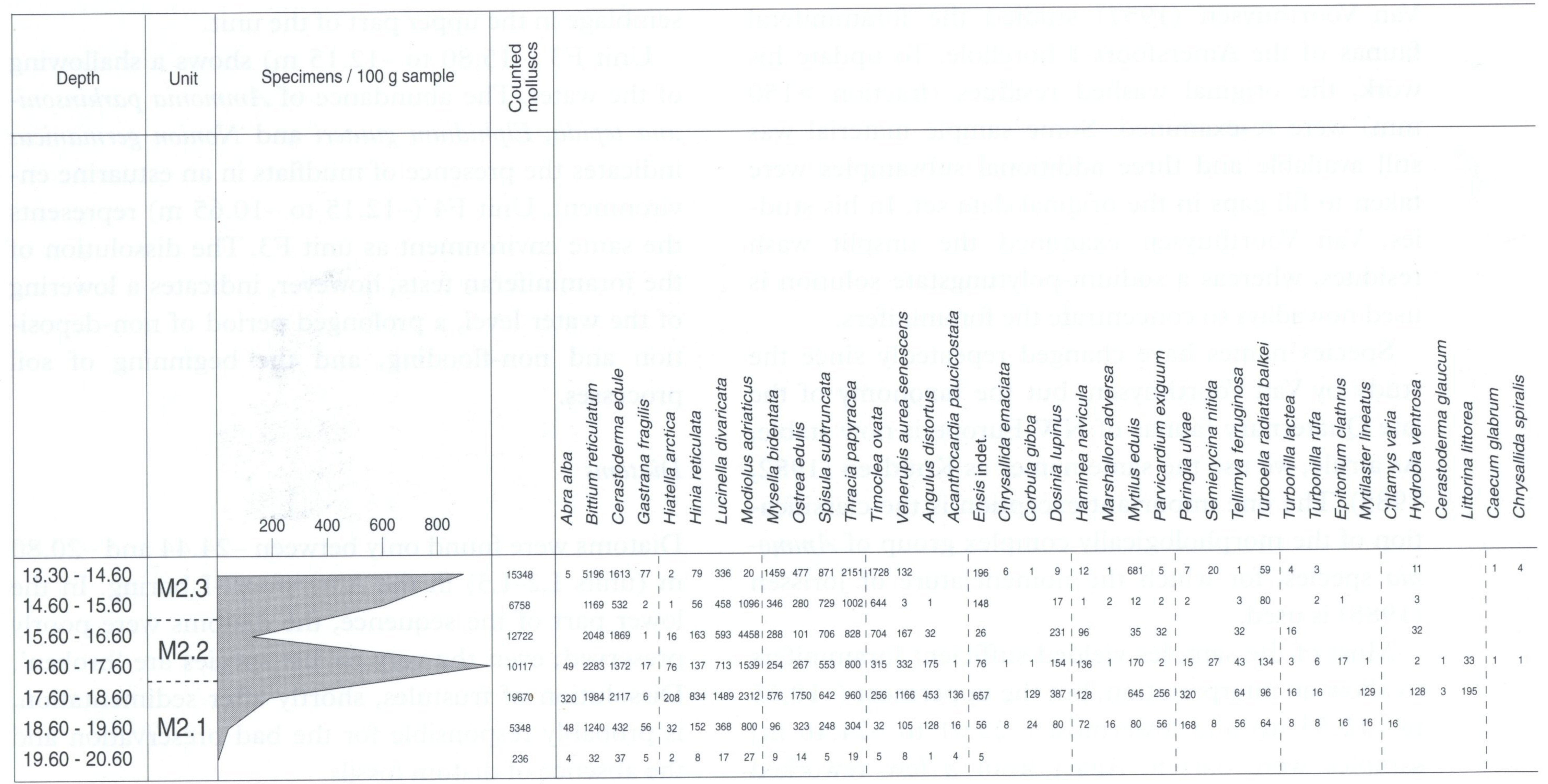

Fig. 7 (p. 204-205). Molluscs and other fossil groups in the Amersfoort-2 borehole (selected species). 


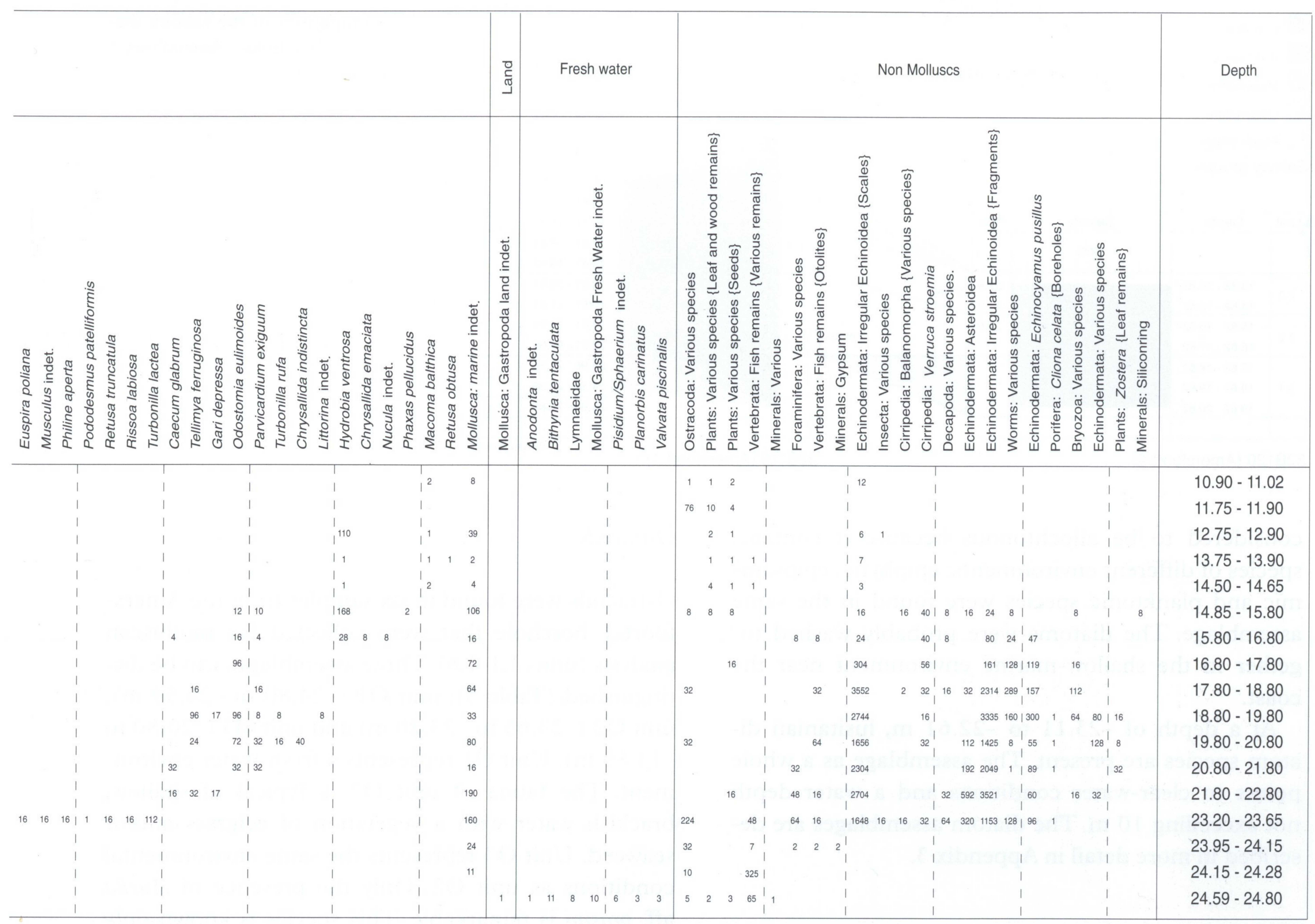

Fig. 6 (continued).

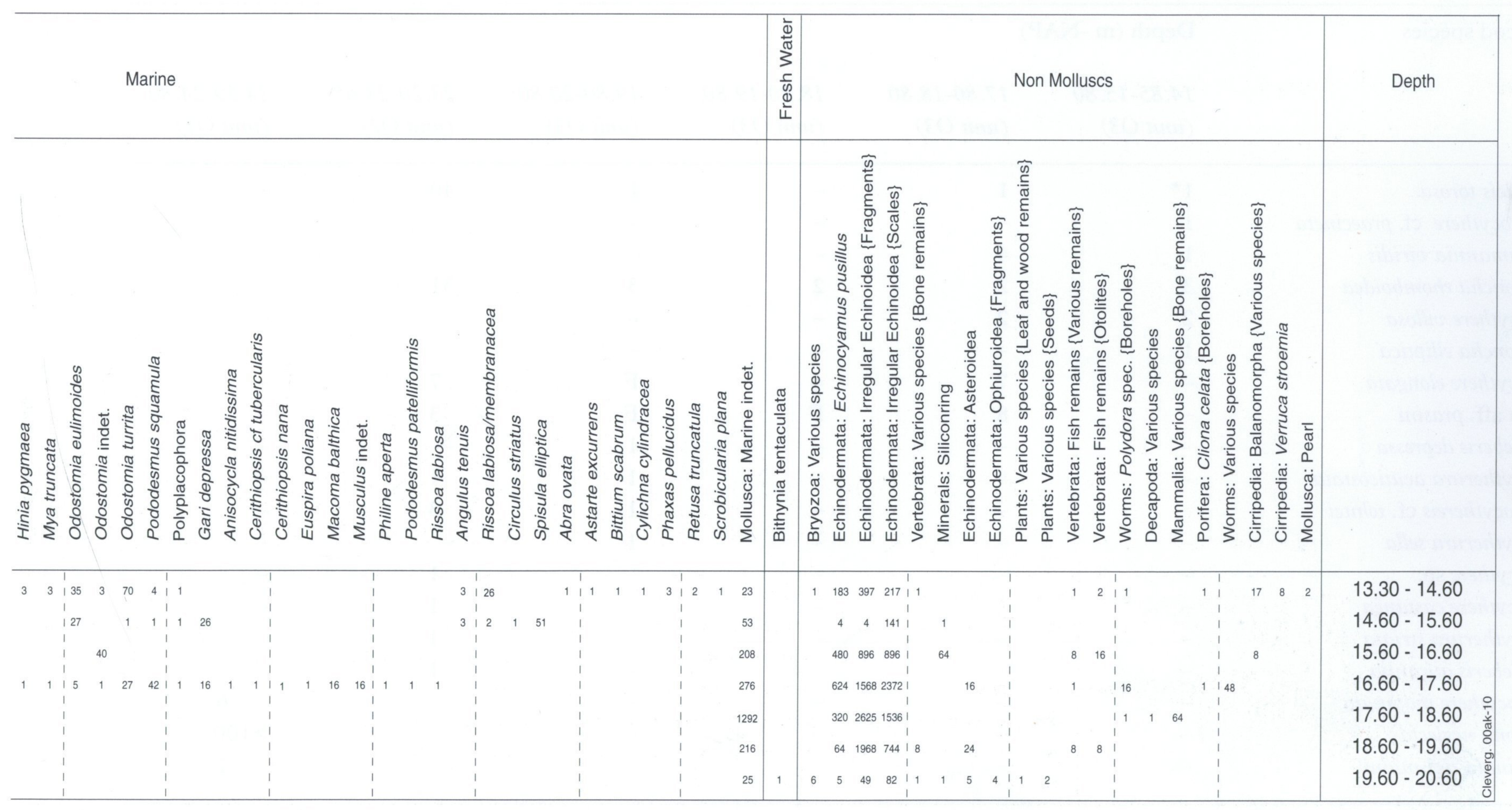

Fig. 7 (continued). 


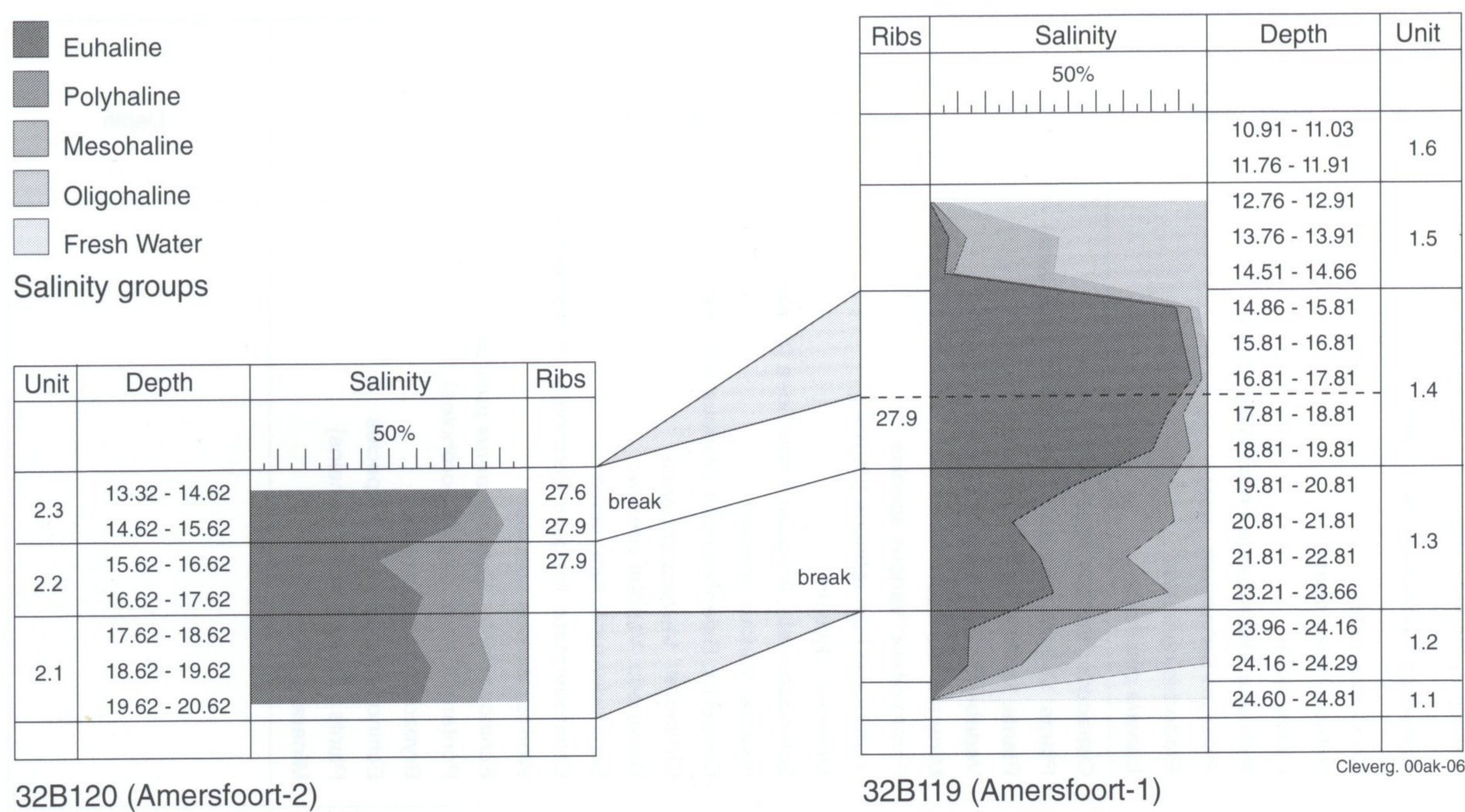

Fig. 8. Comparison of the salinity diagrams from boreholes Amersfoort-1 and Amersfoort-2.

considered to be allochtonous because it contains species of different environments: epiphytic, epipsammic and planktonic species were found in the same assemblage. The diatoms were probably washed together in the shallow-marine environment near the coast.

At a depth of -23.11 to $-22.61 \mathrm{~m}$, lusitanian diatom species are present. The assemblage as a whole points to clear-water conditions and a water depth not exceeding $10 \mathrm{~m}$. The diatom assemblages are described in more detail in Appendix 3.

\section{Ostracods}

Ostracods were found in six samples from the Amersfoort-1 borehole that were collected for molluscan analysis (units L1-L6). Three assemblages can be distinguished (Table 3): unit O1 ( -24.80 to $-24.59 \mathrm{~m})$, unit $\mathrm{O} 2(-23.65$ to $-23.20 \mathrm{~m})$ and unit $\mathrm{O} 3(-20.80$ to $-14.85 \mathrm{~m})$. Unit $\mathrm{O} 1$ represents a fresh-water environment. The fauna of unit $\mathrm{O} 2$ is typical of shallow, brackish water with a vegetation of eelgrass and/or seaweed. Unit $\mathrm{O} 3$ represents the same environmental conditions as unit O2. Only the presence of Aurila aff. prasini is remarkable. This species is known only

Table 3. Ostracods of the Amersfoort-1 borehole. Depths are indicated in meters below NAP.

\begin{tabular}{|c|c|c|c|c|c|c|}
\hline \multirow[t]{2}{*}{ Ostracod species } & \multicolumn{6}{|c|}{ Depth (m-NAP) } \\
\hline & $\begin{array}{l}14.85-15.80 \\
\text { (unit O3) }\end{array}$ & $\begin{array}{l}17.80-18.80 \\
\text { (unit O3) }\end{array}$ & $\begin{array}{l}\text { 18.80-19.80 } \\
\text { (unit O3) }\end{array}$ & $\begin{array}{l}19.80-20.80 \\
\text { (unit O3) }\end{array}$ & $\begin{array}{l}23.20-23.65 \\
\text { (unit } \mathrm{O} 2 \text { ) }\end{array}$ & $\begin{array}{l}24.59-24.80 \\
\text { (unit O1) }\end{array}$ \\
\hline Cyprideis torosa & $1^{\star}$ & 1 & - & 1 & 40 & - \\
\hline Callistocythere cf. praecincta & 1 & - & - & - & - & - \\
\hline Hirschmannia viridis & 1 & 4 & - & - & - & - \\
\hline Loxoconcha rhomboidea & 3 & 2 & 2 & 3 & 31 & - \\
\hline Hemicythere villosa & 2 & 2 & - & - & - & - \\
\hline Loxoconcha elliptica & 1 & - & - & - & - & - \\
\hline Pontocythere elongata & - & 7 & 4 & $\mathrm{~F}$ & 7 & - \\
\hline Aurila aff. prasini & - & 8 & $\mathrm{~F}$ & $\mathrm{~F}$ & 3 & - \\
\hline Xestoleberis depressa & - & - & - & 1 & - & - \\
\hline Semicytherura acuticostata & - & - & - & 1 & 1 & - \\
\hline Carinocythereis cf. whitei & - & - & - & 1 & 3 & - \\
\hline Semicytherura sella & - & - & - & 1 & - & - \\
\hline Leptocythere sp. & - & - & - & - & 1 & - \\
\hline Leptocythere castanea & - & - & - & - & 1 & - \\
\hline Semicytherura striata & - & - & - & - & 1 & - \\
\hline Xestoleberis aurantia & - & - & - & - & 1 & - \\
\hline Limnocythere inopinata & - & - & - & - & - & 6 \\
\hline Candona neglecta & - & - & - & - & - & $>100$ \\
\hline Darwinula stevensoni & - & - & - & - & - & 1 \\
\hline
\end{tabular}

$\star=$ only small valves; $\mathrm{F}=$ only fragments. 


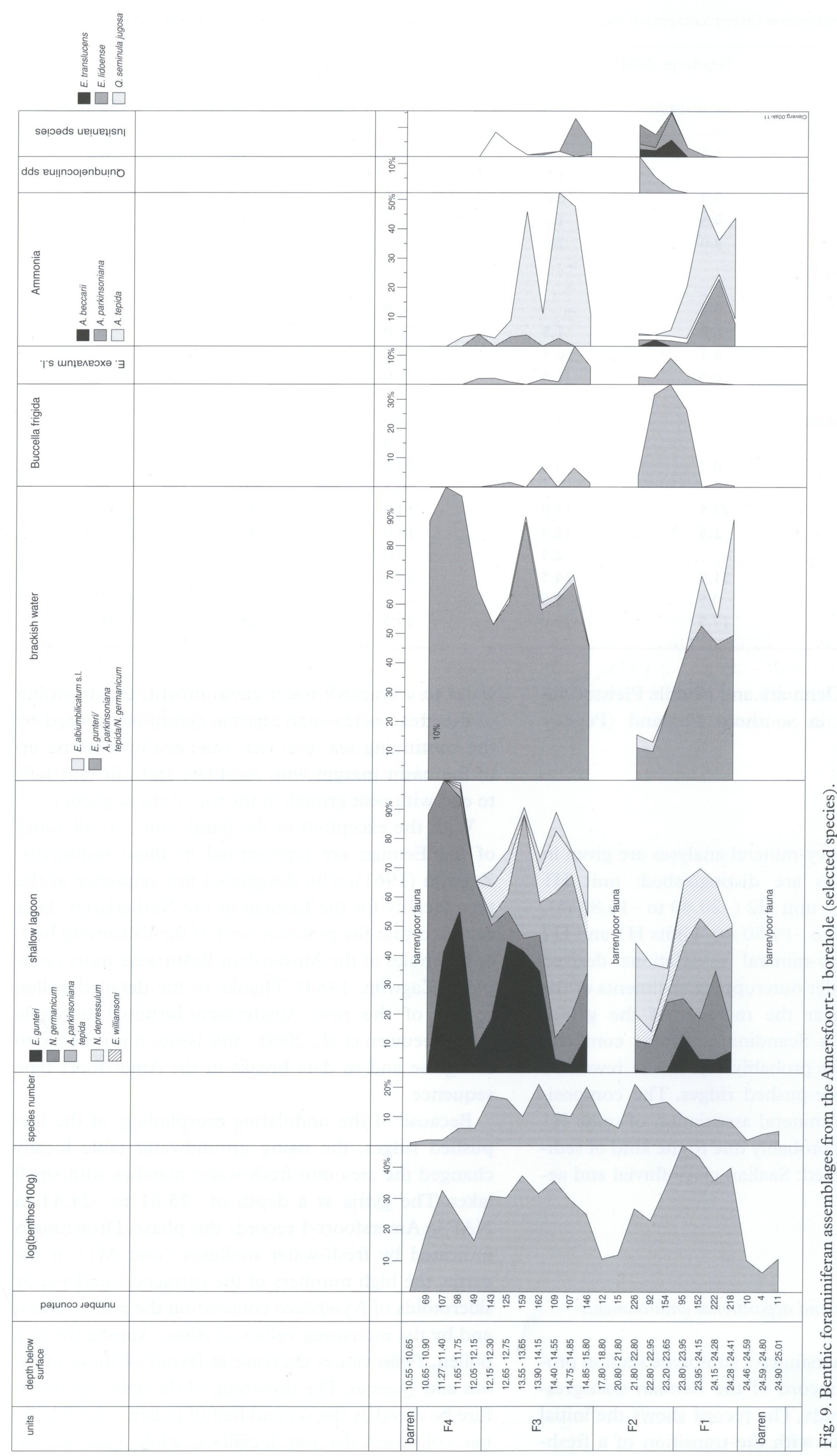


Table 4. Heavy-mineral composition (in percentages) of the Amersfoort-1 borehole. Depths are indicated in meters below NAP.

\begin{tabular}{|c|c|c|c|c|c|}
\hline \multirow[t]{2}{*}{ Mineral } & \multicolumn{5}{|c|}{ Depth (m -NAP) } \\
\hline & $14.50-14.65$ & $16.80-17.80$ & $19.80-20.20$ & $23.20-23.65$ & $25.01-25.80$ \\
\hline tourmaline & 5.5 & 5.5 & 9.5 & 3.0 & 8.0 \\
\hline sillimanite & - & 1.5 & 0.5 & 0.5 & - \\
\hline andalusite & 0.5 & 2.0 & 3.0 & 0.5 & - \\
\hline kyanite & 0.5 & 1.0 & 1.0 & 1.5 & 1.0 \\
\hline staurolite & 2.0 & 2.0 & 3.5 & 3.0 & 2.0 \\
\hline topaze & - & - & - & - & - \\
\hline pumpellyite & - & - & - & - & - \\
\hline sphene s.l. & 0.5 & - & 0.5 & 0.5 & - \\
\hline anatase & 6.0 & 1.5 & 1.0 & 2.5 & 1.0 \\
\hline rutile & 4.5 & 0.5 & 2.0 & 2.5 & 3.0 \\
\hline zircon & 6.0 & 1.5 & 1.0 & 4.5 & 4.5 \\
\hline other volcanic minerals & - & 0.5 & - & - & - \\
\hline hornblende (brown and basaltic) & - & 4.0 & 1.0 & - & 0.5 \\
\hline hypersthene & - & 0.5 & 2.5 & 0.5 & - \\
\hline augite & 0.5 & 5.5 & 10.0 & 2.0 & 4.0 \\
\hline chloritoid & - & - & 0.5 & 0.5 & - \\
\hline hornblende & 23.5 & 15.0 & 14.5 & 18.0 & 17.5 \\
\hline alterite & 1.5 & 12.5 & 14.0 & 10.0 & 8.0 \\
\hline saussurite & - & 2.5 & 2.0 & - & - \\
\hline epidote & 31.0 & 14.5 & 14.0 & 22.0 & 18.0 \\
\hline garnet (cloudy) & 0.5 & 0.5 & - & - & 1.0 \\
\hline garnet (clear) & 17.5 & 29.0 & 19.5 & 28.5 & 31.5 \\
\hline
\end{tabular}

from the Eemian of Denmark and Middle Pleistocene interglacial deposits in southern England (Penney 1989).

\section{Heavy minerals}

The results of the heavy-mineral analyses are given in Table 4. Three units are distinguished: unit $\mathrm{H} 1$ $(-25.80$ to $-23.20 \mathrm{~m})$, unit $\mathrm{H} 2(-20.80$ to $-16.80 \mathrm{~m})$, and unit $\mathrm{H} 3$ ( -14.65 to $-14.50 \mathrm{~m})$. Units $\mathrm{H} 1$ and $\mathrm{H} 2$ comprise local heavy-mineral associations derived from reworking of older outcropping sediments of the ice-pushed ridges near the margins of the glacial basin. Unit H3 has a Scandinavian/Baltic composition, which also most probably represents reworked sediment from the ice-pushed ridges. The composition differs from the mineral association of units $\mathrm{H} 1$ and $\mathrm{H} 2$. This is most probably due to the kind of sediments that are reworked: Saalian glaciofluvial and aeolian material.

\section{Discussion}

\section{Stratigraphical breaks and depositional environments}

At first sight, the Amersfoort-1 stratotype section provides a continuous record of the Eemian transgression in the Netherlands. The record shows the initial flooding by sea water with the transition of a fresh- water to a brackish-water environment, the drowning of the area, increasingly marine conditions caused by the continuing sea-level rise, followed by a silting-up of the basin margin with mudflats and salt marshes, to end with peat growth at the top of the sequence.

With the exception of the basal zone E1, all zones of the Eemian are represented in these sediments. Zagwijn (1961), who designated this sequence as the type locality for the Eemian in the Netherlands, later reported that the pollen record of the Valkenweg bailer boreholes of the Amsterdam Basin were more complete (Zagwijn, 1983). Thanks to the detailed pollen record of the new Amsterdam-Terminal borehole (Van Leeuwen et al., 2000 - this issue) it is possible to recognise and to date breaks in the Amersfoort type sequence.

Because of the undulating morphology of the icepushed ridges, the rising groundwater table locally changed the area into fresh-water marshes with small lakes. The gyttja at a depth of -25.01 to $-24.44 \mathrm{~m}$ NAP in Amersfoort-1 records this phase. Drowning is indicated by fresh-water molluscs (unit M1) in the gyttja, the high numbers of the ostracod Candona, by sklerotoids of Nymphaea counted on the pollen slides, and by the increasing values of Alnus. Among the tree pollen, Pinus values decrease in favour of those of $\mathrm{Al}$ nus and Quercus. The drowning of the area can therefore be dated as the second half of pollen zone E2. Alnus colonised the wet localities, while Quercus was 


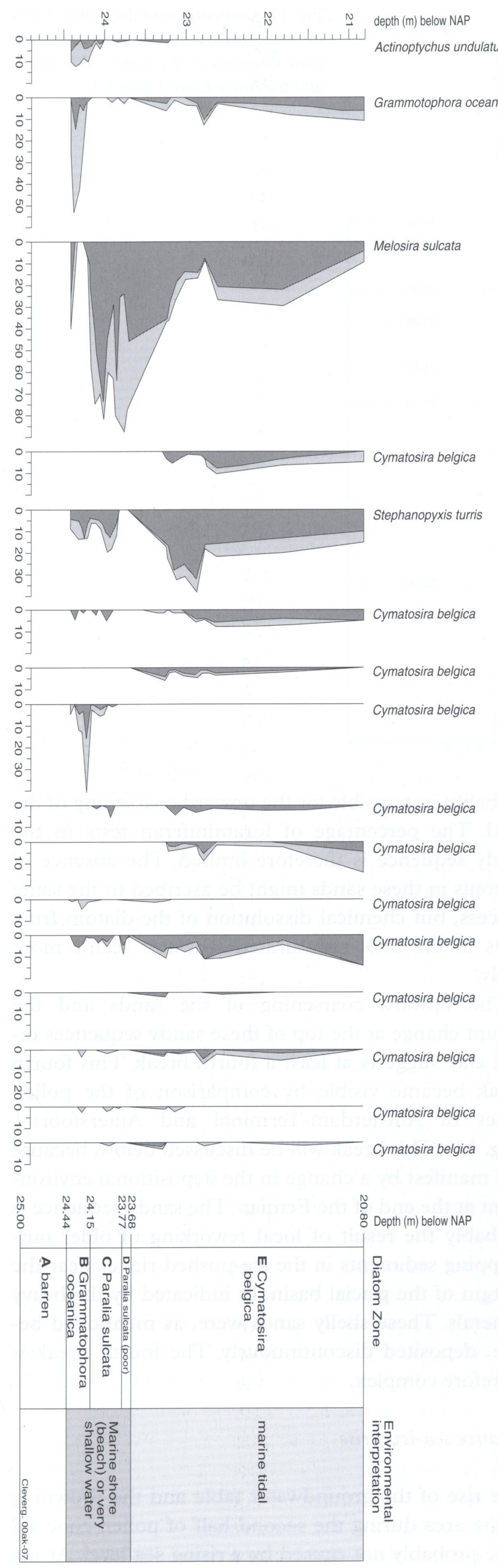

growing on slightly higher and drier ground on the hills. The lacustrine conditions continued into pollen zone E3, when Quercus and Corylus were the most important trees.

The transition from a lacustrine to a brackish environment in Amersfoort-1 took place during zone E4a. The transition was not gradual: it represents an erosional break or an interval of non-deposition. The sudden transition at $-24.44 \mathrm{~m}$ NAP (Fig. 3) is demonstrated by an abrupt increase from approx. $20 \%$ to more than $40 \%$ of the Corylus curve. In the pollen record from the Amsterdam-Terminal site, this increase is gradual and occurs over a sediment thickness of half a meter. The conspicuous change in molluscan assemblages between units M1.2 and M1.3 also supports this phenomenon.

On top of the fine-grained, organic-rich layer at $-23.95 \mathrm{~m}$, a third break is observed. The Corylus curve (Fig.3) shows the break again most clearly: values decrease from over 50 to less than $30 \%$. This decrease is - just like the one described above - much more gradual in the Amsterdam-Terminal borehole (Van Leeuwen et al., 2000 - this issue). The presence of Carpinus at low values, immediately above this boundary, provides another argument to suggest a break. In the Amsterdam-Terminal sequence, the first occurrence of Carpinus coincides with the Taxus maximum $( \pm 10 \%)$. At Amersfoort, the arrival and, in particular, the gradual decrease and eventual disappearance of Taxus are recorded, but its maximum is absent (Fig. 11). The Taxus-maximum pollen zone, which is missing in Amersfoort, is represented by $3 \mathrm{~m}$ of laminated clay in the Amsterdam-Terminal borehole.

According to Zagwijn (1983), the Eemian sea-level highstand was attained at the end of pollen zone E4b, slightly after the Taxus pollen maximum, with the first arrival of Carpinus. This indicates, together with the evidence based on the mollusc, ostracod and foraminifer faunas, that the third break reflects erosion and non-deposition because of the upward shift of the facies zones with the rising sea level.

The coarsening-upward sequence of shell-rich sands (unit L5) between -22.60 and -14.79 m NAP represents the transition of pollen zone $\mathrm{E} 4 \mathrm{~b}$ and the greatest part of pollen zone E5. The sands are devoid of pollen, so that the position of the boundary to pollen zone E5 could not be well established. A sample of clayey sand at a depth of -21.33 m NAP gave a poor pollen spectrum (Fig. 3). Because of the relatively low value of Carpinus, this spectrum suggests that the sand was deposited during pollen zone E4b. The clays and sandy clays (unit L1) overlying this sandy sequence at a depth of -14.79 to $-10.51 \mathrm{~m}$ NAP were deposited during the second half of pollen 


\begin{tabular}{|c|c|c|c|}
\hline & \multirow{2}{*}{$\begin{array}{l}\begin{array}{l}\text { Regional zonation } \\
\text { (Zagwijn, 1961\&1975) }\end{array} \\
\text { Pinus, Betula }\end{array}$} & \multicolumn{2}{|c|}{$\begin{array}{l}\text { Zonation Amsterdam-Terminal } \\
\text { (van Leeuwen et al., 2000) }\end{array}$} \\
\hline & & $\begin{array}{l}\text { Betula, Juniperus, } \\
\text { Hippophaë, Artemisia }\end{array}$ & AT 16 \\
\hline $\mathrm{E} 6 \mathrm{a}$ & $\begin{array}{l}\text { Picea, Abies, Alnus, } \\
\text { Carpinus, Quercus, Pinus }\end{array}$ & $\begin{array}{l}\text { Picea maximum, Abies } 3 \% \\
\text { decrease of Carpinus }\end{array}$ & AT 15 \\
\hline \multirow[t]{2}{*}{ E5 } & \multirow{2}{*}{$\begin{array}{l}\text { Carpinus, Quercus, Alnus } \\
\text { Corylus, Picea }\end{array}$} & Carpinus maximum & AT 14 \\
\hline & & $\begin{array}{l}\text { Carpinus }>2 \% \\
\text { Taxus }<5 \%\end{array}$ & AT 13 \\
\hline \multirow[t]{2}{*}{$E 4 b$} & \multirow[t]{2}{*}{$\begin{array}{l}\text { Taxus, Corylus, Quercus } \\
\text { Picea, Carpinus }\end{array}$} & $\begin{array}{l}\text { Carpinus }<2 \% \\
\text { decrease of Taxus }\end{array}$ & AT 12 \\
\hline & & Taxus maximum & AT 11 \\
\hline \multirow[t]{2}{*}{$E 4 a$} & \multirow[t]{2}{*}{ Corylus with Quercus } & $\begin{array}{l}\text { Corylus maximum } \\
\text { Taxus ca. } 1 \%\end{array}$ & AT 10 \\
\hline & & further increase of Corylus & AT 9 \\
\hline \multirow{4}{*}{ E3 } & \multirow{4}{*}{$\begin{array}{l}\text { Quercus } \\
\text { increase of Corylus } \\
\text { decrease of Ulmus }\end{array}$} & increase of Corylus & AT 8 \\
\hline & & $2^{\text {nd }}$ maximum Pinus & AT 7 \\
\hline & & Quercus maximum & AT 6 \\
\hline & & increase of Betula & AT 5 \\
\hline E2 & $\begin{array}{l}\text { Pinus } \\
\text { low percentage of Quercus, } \\
\text { Ulmus, Fraxinus, Alnus }\end{array}$ & $\begin{array}{l}1^{\text {st }} \text { maximum Pinus } \\
\text { (Ulmus maximum) }\end{array}$ & AT 4 \\
\hline E1 & Betula, low percentage of Pinus & $\begin{array}{l}\text { Betula } \\
\text { low percentage of Pinus, } \\
\text { Juniperus }\end{array}$ & AT 3 \\
\hline \multirow{2}{*}{ 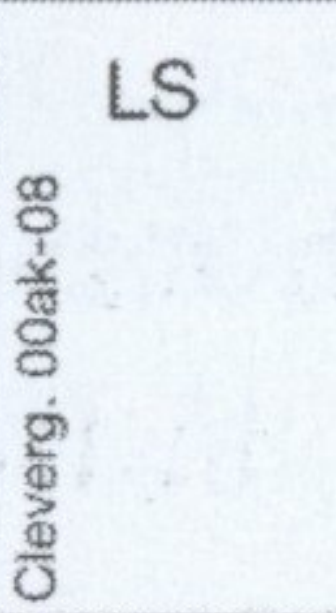 } & \multirow{2}{*}{ non-arboreal pollen high } & $\begin{array}{l}\text { increase Juniperus } \\
\text { Artemisia, Cyperaceae, } \\
\text { Gramineae, Helianthemum }\end{array}$ & AT 2 \\
\hline & & Pinus high in the upper part & AT 1 \\
\hline
\end{tabular}

zone E5. This is deduced from the presence of Abies occurring in low percentages in the sediments. Abies frequencies increase upwards in the clay and sandy clays to values of $5 \%$.

During pollen zones E4b (the end) and E5, over 20 $m$ of clay was deposited in the Amsterdam-Terminal borehole. The same interval (pollen zones E4b and E5) is represented at Amersfoort by about $8 \mathrm{~m}$ of coarse shelly sands. As already mentioned in the section above on the molluscs, these coarse sands were deposited discontinuously. Because of the restricted resolution of the pollen only the molluscs of Amersfoort-1 and Amersfoort-2 (see also Appendix 1) indicate two hiatuses in the sands (Fig. 8). The ostracods also showed changes in environmental conditions at these depths (Table 3).

In Amersfoort-2, clay sedimentation started earlier. It was dated to pollen zone E5, when Carpinus still reached values of about 30 (Fig. 4). Because of the presence of Abies in one of the spectra, the end of the sandy sequence can, however, be dated to the younger part of pollen zone E5, as in Amersfoort-1. The matter of the occurrence of Abies in the Netherlands will be discussed below.

The water depth at the basin margin never exceeded 10-15 $\mathrm{m}$ during the Eemian highstand. Wave action and related hydrodynamic circumstances were

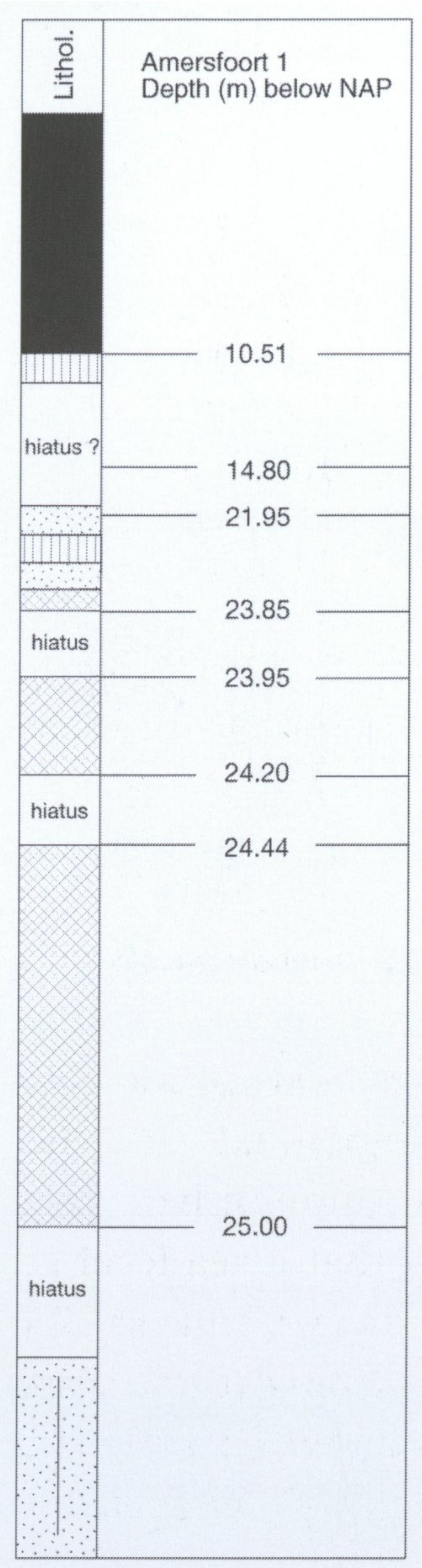

Fig. 11. Comparison of the pollen zones of the Amsterdam-Terminal borehole (van Leeuwen et al., 2000 - this issue) and the Amersfoort-1 borehole. probably responsible for the upward coarsening of the sand. The percentage of foraminiferan tests in the sandy sequence is therefore limited. The absence of diatoms in these sands might be ascribed to the same process, but chemical dissolution of the diatom frustules in the $\mathrm{SiO}_{2}$-unsaturated seawater seems more likely.

The upward coarsening of the sands and the abrupt change at the top of these sandy sequences into a clay suggests at least a fourth break. This fourth break became visible by comparison of the pollen zones of Amsterdam-Terminal and Amersfoort-1 (Fig. 11). This break will be discussed below, because it is manifest by a change in the depositional environment at the end of the Eemian. The sandy sequence is probably the result of local reworking of older outcropping sediments in the ice-pushed ridges near the margin of the glacial basin, as indicated by the heavy minerals. These shelly sands were, as mentioned before, deposited discontinuously. The fourth break is therefore complex.

\section{Relative sea-level rise}

The rise of the groundwater table and the drowning of the area during the second half of pollen zone E2 were probably not caused by a rising sea level. At the 


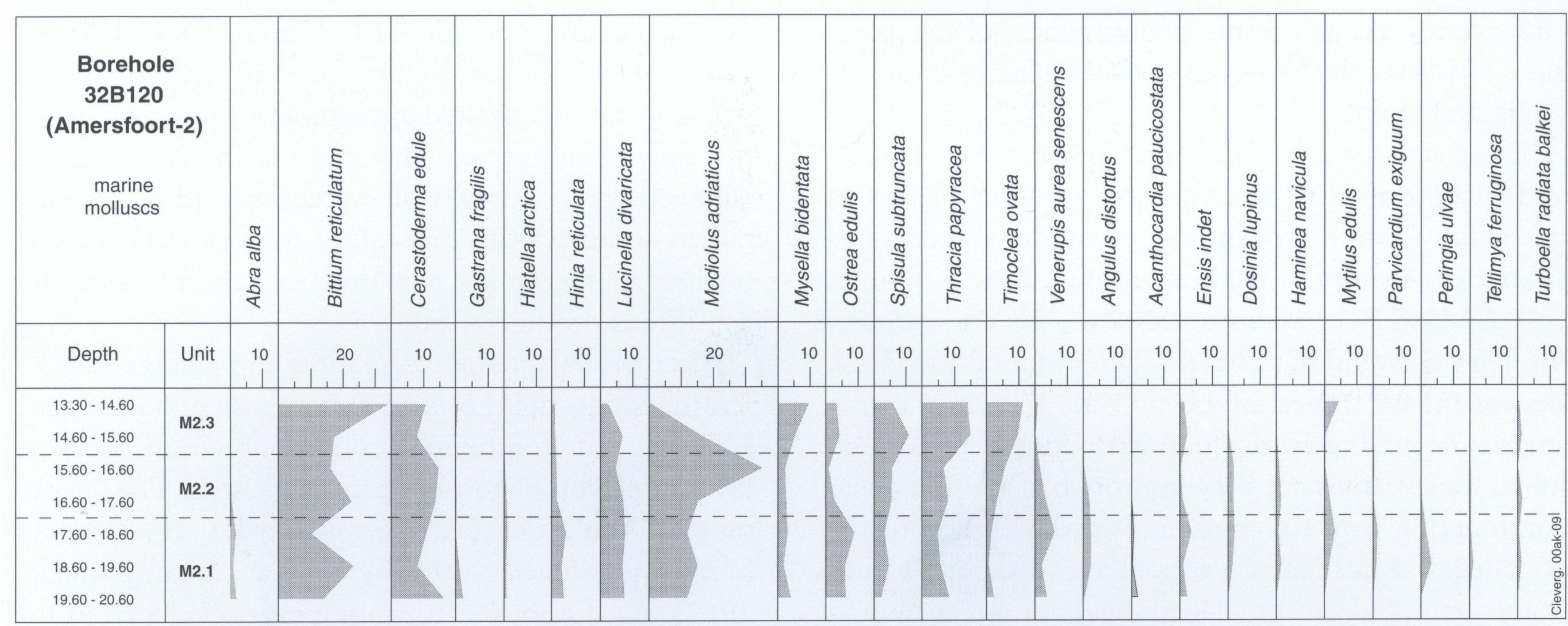

Fig. 12. Mollusc diagram of the Amersfoort-2 borehole (selected species).

time, sea level was still below $-60 \mathrm{~m} \mathrm{NAP}$, as indicated by sequences in the western Netherlands and the Southern Bight of the North Sea (unpublished data NITG-TNO). It is highly unlikely that a sea level at this depth would influence a groundwater table at -25 $m$ NAP. This suggests that the drowning of the area reflected a normalisation of the groundwater situation after the Saalien glaciation, and probably also an increase in precipitation.

In the Amsterdam Basin, the top of the $-40 \mathrm{~m}$ deep sill was flooded during pollen zone E3 (De Gans et al., 2000 - this issue; Van Leeuwen et al., 2000 - this issue). In the Amersfoort-1 borehole, the first marine sediments date from pollen zone E4a. This depth of $-24.44 \mathrm{~m}$ NAP is an important height for the Dutch Eemian sea-level curve. According to Zagwijn (1983) the Eemian highstand reached $-15 \mathrm{~m}$ NAP. It is dated to pollen zone E4b.

The clays and sandy clays (unit L6) deposited at a depth of -14.65 to $-10.90 \mathrm{~m}$, at the top of the coarse shelly sands (unit L5) in the Amersfoort-1 borehole, suggest a still rising sea level during pollen zone E5 (Abies). The molluscan and foraminiferan assemblages in the clays and sandy clays, however, indicate a shallowing of the lagoon, which developed into an estuary-like water body surrounded by mudflats. This suggests a lowering of the sea level during the second half of pollen zone E5. The change of the environmental conditions can be explained only as resulting from lowering of the sea level. The clay trapped in the deeper parts of the glacial basins during the Carpinus pollen zone (E5), settled during the latter part of pollen zone E5, near the margins of the glacial basins.

In the Amersfoort Basin, the genesis of the coastal area shows no similarity with the Holocene. Both the steeper relief after the Saalian glaciation and the (local and regional) morphology in the coastal zone area during the Eemian are in no way similar to the beginning of the Holocene (see also De Gans et al., 2000 this issue).

\section{Depositional environment and climate}

As already discussed, sedimentation began with carbonate-rich gyttja deposited in a nutrient-rich, shallow lake. The change to brackish conditions is accompanied by some erosion. Cerastoderma glaucum is the dominant mollusc species in the fine-grained organicrich layer between -24.44 and -23.95 m NAP. This and some other species point to deposition in water of only a few metres deep, under varying temperature and salinity conditions. The fauna (molluscs, ostracods and foraminifers) in the organic-rich sands and overlying shell-rich clays and sands between -23.95 and $-20 \mathrm{~m} \mathrm{NAP}$, indicate a further increase of the water depth during pollen zone E3/E4a. The abundance of Nonion depressulum and Cerastoderma edule show, however, that a lagoonal environment with varying salinity conditions persisted.

The organic-rich sands and overlying shell-rich clays and sands between -23.95 and $-20 \mathrm{~m}$ NAP represent the transition from the Taxus E4b zone to the Carpinus E5 zone, the Taxus maximum being absent in the Amersfoort-1 borehole. During the Taxus phase (pollen zone E4b), the Eemian sea-level highstand reached about $10 \mathrm{~m}$ below NAP (Zagwijn, 1983). This means that the water depth of the basin at the Amersfoort-1 site did not exceed 10-15 m during this phase. This is confirmed by the presence of epiphytic faunas (molluscs such as Bittium and Turboella, and ostracods) and epiphytic diatoms. Besides, the vegetation of Zostera and algae indicates clear-water conditions, and consequently little suspended material. The presence of oysters confirms these environmental cir- 
cumstances. A significant phenomenon is the presence of lusitanian and even warmer species in all investigated biota.

The Cerastoderma edule at a depth between -20.00 and $-15.00 \mathrm{~m}$ NAP has an equal number of ribs as the (rarely found) maximum of modern specimens (Table 2). Using the relationship found by Koulman \& Wolff (1977) between number of ribs and salinity, the salinity would have been of the order of $40-45 \%$. Because these values are beyond the tolerance of the species occurring in the Eemian deposits of Amersfoort, these values are very improbable. This leads, in combination with the arguments given earlier, to the conclusion that salinity was well above salinity values of the open, present-day North Sea, but not as high as suggested by the rib-number/salinity formula. The abundant presence of Mysella, a species living between the spines of Echinocardium, indicates that the salinity showed little variation, as Echinocardium is an echinoid of open-marine waters. Echinocardium can tolerate a higher salinity very well.

In the Amersfoort borehole, the molluscan assemblage of the sandy sequence between -20.00 and $-15.00 \mathrm{~m}$ NAP is generally considered to represent the warmest interval of the Eemian. According to De Beaulieu \& Reille (1992), Van Andel \& Tzedakis (1996) and Tzedakis (1999), the major expansion of the mediterranean forest characterised by Olea and evergreen oak was synchronous with the Taxus phase in the rest of Europe and represents the time of maximum summer insolation.

The present authors consider that local geographical conditions - in particular the position of the borehole at the margin of a sheltered bay of the Eemian Sea - are responsible for a higher water temperature and therefore also a higher salinity at the end of pollen zone $\mathrm{E} 4 \mathrm{~b}$ and the first part of pollen zone $\mathrm{E} 5$. They agree with De Beaulieu \& Reille (1992) and Van Andel \& Tzedakis (1996) that the Taxus phase represents the warmest phase of the Eemian.

The abrupt change from coarse sands into a clay represents a hiatus at $-14.79 \mathrm{~m}$, as discussed. The coarse shelly sands were deposited at a depth of approx. $10 \mathrm{~m}$. The change in depositional environment, especially of the hydrodynamic conditions, starts in the second part of pollen zone E5. The presence of Cerastoderma glaucum, Hydrobia neglecta and Peringia ulvae suggests shallow sublittoral conditions, and lower salinity. In addition, the foraminiferan assemblage (abundance of Ammoni parkinsiniana tepid, Elphidium gunteri and Nonion germanicus) indicates a decrease of the water depth. Both the molluscs and the foraminiferan assemblages indicate the presence of tidal marshes. It is concluded therefore that the clay- rich succession between -14.79 and $-10.51 \mathrm{~m} \mathrm{NAP}$ was deposited in a shallow-marine, intertidal and probably also supratidal environment. The peat above the clays demonstrates that the marine environment changed finally into a fresh-water environment during pollen zones E5/E6. The fall of the sea level became obvious at the end of the Eemian, when fresh-water conditions prevailed again.

After the salt-marsh vegetation had changed into a fen-marsh during the Abies/Picea phase of pollen zone E5, the environmental conditions soon became favourable for oligotrophic peat growth. The beginning of the Ericaceae/Sphagnum peat development has been assigned to the Weichselian stage (Zagwijn, 1961) but it appears from the pollen evidence in the Netherlands' glacial basins that the oligotrophic peat growth had already begun in some places during the Carpinus phase (pollen zone E5). Picea was already represented as a local element in this oligotrophic peat. Outside the glacial basins, also in areas with this oligotrophic peat growth, Picea was also present in pollen zone E4b. In the general scheme of the Netherlands' pollen zonation of the Eemian, Picea is placed, however, in pollen zone E5 (Zagwijn \& van Staalduinen, 1975).

Pollen zone E5 is in this scheme, apart from the presence of Carpinus and Picea, also characterised by the occurrence of Abies. The question at what time Abies became an important tree during the Eemian in the Netherlands was already mentioned by Vermeer Louman (1934) and Van der Vlerk \& Florschütz (1953). At Amersfoort, Abies became important to the end of zone E5 and probably also during the first part of pollen zone E6. Elsewhere in Europe, Abies was an important woodland element even in the first part of the Carpinus phase.

Because of the change in the environmental conditions as recorded at Amersfoort, it is presumed that Abies reached its western limit in the Netherlands during the late Eemian. In particular, the sediments of new intertidal areas near the margins of glacial basins, which developed during the second part of the Carpinus phase, favoured the preservation of the Abies pollen. In the Amsterdam Basin succession (Van Leeuwen et al., 2000 - this issue), Abies is also found in the uppermost sediments dated as Eemian. Whether these intertidal areas were a favourable biotope for Abies trees, and therefore influenced the representation of Abies in the pollen zone E5 and probably E6, is still an open question.

It can safely be said that the lowering of the sea level must have coincided with an extension of the ice caps in Europe and North America. The extent to which Abies gained advantage from the changes in 'at- 
mospheric conditions' is still unclear. In comparison with Picea, Abies does not appreciate cold winters and cold springs. Indirectly, the presence and expansion of Abies to its western limit can be explained as the maintenance of the oceanic climate during the last part of the Carpinus zone (E5). Colder winters and short cold periods during spring finally resulted in a decrease of Abies, and, in turn, favoured the coniferous species Pinus and Picea of the evergreen boreal forest.

\section{Conclusions}

The stratotype locality is situated in the predominantly sandy marginal facies of a bay of the Eemian North Sea in the central part of the Netherlands. The borehole consists of an Eemian sequence of about $15 \mathrm{~m}$ thick, in which all the northern European Eemian pollen zones are present, except E1 (Betula zone). The pollen record is punctuated by a number of short breaks, resulting from erosion and/or non-deposition during the marine transgression. The position and relative length of these breaks are evident when the record is compared with that from the AmsterdamTerminal borehole in the Amsterdam Basin (Fig. 11). The latter consists of a clay-rich Eemian sequence of over $40 \mathrm{~m}$ thick, representing the deeper central part of a similar basin (Van Leeuwen et al., 2000 - this issue; De Gans et al., 2000 - this issue). It can therefore be concluded that the resolution of the pollen record of the Amersfoort-1 type locality is limited. Amsterdam-Terminal seems to be a good parastratotype locality for the northern and central Netherlands.

Because of a restricted exchange between the North Sea and the glacial basins, specific environmental conditions occurred in the basins throughout the marine phase of the Eemian in the Amersfoort Basin. The presence of Cerastoderma edule, with an increased number of ribs on its shells, is an expression of these specific conditions. Lusitanian and mediterranean species are present throughout the marine sequence. At the transition from pollen zone E4b to E5, and probably during the very first part of pollen zone E5 (the highstand of the Eemian sea) sand was eroded from the ice-pushed ridges, as is indicated by heavy-mineral analyses. The coarse sands were transported to the shallow waters of the basin margin, which resulted in the maintenance of a sandy floor and particular environmental conditions in the bay.

The persistence of the lusitanian faunas, after the Taxus maximum (pollen zone E4b) confirm this specific environment with higher water temperatures. It does not imply that the duration of the climatic opti- mum of the Eemian was longer. Local environmental circumstances, resulting from the morphology and hydrodynamic conditions near the margins of the glacial basins, created a specific biotope that favoured the growth of lusitanian species also after the Taxus maximum. Therefore, it is thought that the climate during the first part of the Eemian was already a few degrees warmer than during the Holocene. The Taxus pollen maximum represents the Eemian climatic optimum (cf. Tzedakis et al., 1999).

Finally, it is concluded that Abies reached its western limit in the Netherlands at the end of pollen zone E5. A lowering of the sea level during the interval that Abies became an important tree is deduced from the change in environmental conditions, which also led to the development of mudflats and salt marshes near the margins of the glacial basin,. Locally, eutrophic peat growth started on these mud flats and salt marshes. These eutrophic peats (under fresh-water conditions) changed into oligotrophic peats at the end of the Eemian and/or during the first part of the Early Weichselian. While Abies disappeared, Picea and Pinus became the dominant trees in the area with oligotrophic peat growth.

\section{Acknowledgements}

We thank NITG-TNO for supporting our research on the Eemian of the Netherlands. We are very grateful to Dr. D.J. Beets for fruitful discussions on the biostratigraphic and sedimentary aspects of the Eemian in the glacial basins.

We also thank Rob van Galen, Ria Veldkamp and Rita Vreugdenburg for preparing and counting the pollen slides, Heleen Klaver-Koolmees and Marianne Koolen-Eekhout for the preparation of the foraminiferal samples and their identification, and Ingrid Geutskens for the identification of the diatom assemblages. Finally, we are grateful to Phil Gibbard, Aleid Bosch, Nienke Cleveringa and Rob van Galen for text correction.

\section{References}

De Beaulieu, J.L. \& Reille, M., 1992. Long Pleistocene pollen sequences from the Velay Plateau (Massif Central France), 1. Ribains Maar. Vegetation History and Archaeobotany 1: 223-242.

De Gans, W., De Groot, Th. \& Zwaan, H., 1987. The Amsterdam basin, a case study of a glacial basin in the Netherlands. In: J.J.M. van der Meer (ed.): Tills and glaciotectonics. Proceedings of an INQUA symposium on genesis and lithology of glacial deposits (Amsterdam, 1986): 205-216.

De Gans, W., Beets, D.J. \& Centineo, M.C., 2000. Late Saalian and Eemian deposits in the Amsterdam glacial basin. In: Van Kolfschoten, Th. \& Gibbard, P.L. (eds.): The Eemian - local sequences, global perspectives. Geologie en Mijnbouw / Nether- 
lands Journal of Geosciences 79: 147-160 (this issue).

Eisma, D., 1965. Shell-characteristics of Cardium edule L. as indicators of salinity. Netherlands Journal of Sea Research 2: 493-540.

Eisma, D., Mook, W.G. \& Laban, C., 1981. An early Holocene tidal flat in the Southern Bight. International Association of Sedimentologists Special Publication 5: 229-237.

Haake, F.W., 1962. Untersuchungen an der Foraminiferen-Fauna im Wattgebiet zwischen Langeoog und dem Festland. Meyniana 12: 25-64.

Jelgersma, S. \& Breeuwer, J.B., 1975. Toelichting bij de kaart glaciale verschijnselen gedurende het Saalien, $1: 600.000$. In: Zagwijn, W.H. \& Van Staalduinen C.J. (eds.): Toelichting bij geologische overzichtskaarten van Nederland. Rijks Geologische Dienst (Haarlem): 93-103.

Jessen, K. \& Milthers, V., 1928. Stratigraphical and paleontological studies of interglacial fresh-water deposits in Jutland and Northwest Germany. Danmarks Geologiske Undersøgelse II Raekke 48: 1-379.

Jorissen, F.J., 1988. Benthic foraminifera from the Adriatic Sea; principles of phenotypic variation. Utrecht Micropaleontological Bulletin 37: $176 \mathrm{pp}$.

Knudsen, K.-L., 1982. Foraminifers. In: Olausson, E. (ed.): The Pleistocene/Holocene boundary in south-western Sweden. Sveriges Geologiska Undersøkning C 794: 148-177.

Knudsen, K.-L., 1985. Foraminiferal faunas in Eemian deposits of the Oldenbüttel area near the Kiel Canal, Germany. Geologisches Jahrbuch A 86: 27-47.

Konradi, P.B., 1976. Foraminifera in Eemian deposits at Stensigmose, southern Jutland. Danmarks Geologiske Undersøgelse II Raekke 105: 55 pp.

Koulman, J.G. \& Wolff, W.J., 1977. The Mollusca of the estuarine region of the rivers Rhine, Meuse and Scheldt in relation to the hydrography of the area. V. The Cardiidae. Basteria 41:21-32.

Lutze, G., 1965. Zur Foraminiferen-Fauna der Ostsee. Meyniana 15: $75-142$.

Matoba, Y., 1970. Distribution of Recent shallow water foraminifera of Matsushima Bay, Miyagi Prefecture, Northeast Japan. Science Reports Tohoku University Series 2 42: 1-85.

Murray, J.W., 1971. An atlas of British Recent foraminifers. Heinemann (London): $244 \mathrm{pp}$.

Penney, D.A., 1989. Microfossils (Foraminifera, Ostracods) from an Eemian (last interglacial) tidal flat sequence in South-West Denmark. Quarternary International 3/4: 85-91.

Richter, G., 1967. Faziesbereiche rezenter und subrezenter Wattensedimente nach ihren Foraminiferen-Gemeinschaften. Senckenbergiana Lethaea 48: 291-355.

Tebble, N., 1966. British bivalve seashells. British Museum (London): $212 \mathrm{pp}$.

Tzedakis, P.C., 1999. The last climatic cycle at Kopais, central Greece. Journal of the Geological Society of London 156: 425434.

Tzedakis, P.C. \& Bennett, K.D., 1995. Interglacial vegetation succession a view from southern Europe. Quarternary Sience Reviews 14: 967-982.

Uffenorde, H., 1982. Zur Gliederung des klastischen Holozäns im mittleren und nordwestlichen Teil der Deutschen Bucht (Nordsee) unter besonderer Berücksichtigung der Foraminiferen. Eiszeitalter und Gegenwart 32: 177-202.

Van Andel, T.H. \& Tzedakis, P.C., 1996. Palaeolithic landscapes of Europe and environs, 150.000-25.000 years ago: an overview. Quarternary Science Reviews 15: 481-500.

Van Benthem Jutting, T., 1943. Mollusca (I) C. Lamellibranchia. Fauna van Nederland: 12. A.W. Sijthoff's Uitgeversmaatschappij N.V. (Leiden): 477 pp.

Van der Vlerk, I.M. \& Florschütz, F., 1953. The palaeontological base of the sub-division of the Pleistocene in The Netherlands. Verhandelingen van de Koninklijke Akademie van Wetenschappen le reeks, $20(2): 1-58$.

Van Leeuwen, R.J., Beets, D., Bosch, J.H.A., Burger, A.W., Cleveringa, P., Van Harten, D., Herngreen, G.F.W., Langereis, C.G., Meijer, T., Pouwer, R. \& De Wolf, H., 2000. Stratigraphy and integrated facies analysis of the Eemian in the Amsterdam-Terminal borehole, the Netherlands. In: Van Kolfschoten, Th. \& Gibbard, P.L. (eds.): The Eemian - local sequences, global perspectives. Geologie en Mijnbouw / Netherlands Journal of Geosciences 79: 161-196 (this issue).

Van Voorthuysen, J.H., 1957. Foraminiferen aus dem Eemien (Riss-Würm-Interglazial) in der Bohrung Amersfoort-1 (Locus typicus). Mededelingen van de Geologische Stichting 11:27-39.

Van Voorthuysen, J.H., 1960. Die Foraminiferen des Dollart-EmsEstuarium. Verhandelingen van het Koninklijk Geologisch Mijnbouwkundig Genootschap 19: 237-269.

Vermeer-Louman, G.G., 1934. Pollen-analytisch onderzoek van den Westnederlandschen bodem. Ph.D. thesis Amsterdam University: $184 \mathrm{pp}$.

Zagwijn, W.H., 1961. Vegetation, climate and radiocarbon datings in the Late Pleistocene of the Netherlands. Part I: Eemian and Early Weichselian. Mededelingen van de Geologische Stichting, Nieuwe Serie 14: 15-45.

Zagwijn, W.H., 1983. Sea-level changes in the Netherlands during the Eemian. Geologie en Mijnbouw 62: 437-450.

Zagwijn, W.H. \& Van Staalduinen, C.J. (eds.), 1975. Toelichting bij geologische overzichtskaarten van Nederland. Rijks Geologische Dienst (Haarlem): 134 pp.

\section{Appendix 1: Molluses from Amersfoort-2}

In borehole 32B120, (Amersfoort-2) pre-Eemian glaciofluvial deposits occur between -24.60 and -20.60 $\mathrm{m}$. Seven samples of the overlying sandy deposits between -20.60 and $-13.30 \mathrm{~m}$. have been re-investigated. The overlying marine clay was not included in the molluscan analysis (Fig. 12). Most of the shell material is rather well to very well preserved; only a minor part of the shells shows traces of leaching. All molluscan assemblages (Fig. 7), therefore, are considered to be present in situ and to be (par)autochthonous.

The environmental conditions are quite similar to those from units M1.3 and M1.4 of borehole 32B119 (Amersfoort-1), although some differences are apparent. The assemblages are predominantly high sublittoral (between the wave base and the lowest low watermark) and point to euhaline salinities. Several rib counts on specimens of Cerastoderma edule point to 'hypersaline' values (Table 2).

Bittium reticulatum is the dominant species in most samples, indicating seaweed and/or eelgrass vegetation. Other eelgrass (epiphytic) species occur as well: Turboella radiata balkei, Haminea navicula, Parvicardium exiguum, etc. Although other species dominate in several samples, they do not indicate significant environmental change. All the investigated molluscan assemblages indicate a lagoonal environment.

Differences between both Amersfoort boreholes are most obvious at two levels. These differences are ex- 
plained as resulting from breaks in sedimentation. Two breaks can be recognised. The first is located in borehole Amersfoort- 1 at the transition between units M1.2 and M1.3. It is thought that the assemblages between -20.60 and -17.60 NAP of the Amersfoort-2 borehole correlate with this break in Amersfoort-1. The second break is present at the top of the sandy facies of Amersfoort-2 at a depth of $13.30 \mathrm{~m}$. The assemblages between -20.55 and $-17.55 \mathrm{~m}$ NAP in Amersfoort- 1 are considered to represent this break in Amersfoort-2. These two breaks can be recognised in the species composition of the assemblages in both boreholes, but also in the ecological change as indicated by the assemblages. This is exemplified here by the change in salinity preference of the assemblages in both boreholes (Fig. 8).

\section{Appendix II: foraminiferan zonation in the Amers- foort-1 borehole}

\section{Unit F1}

Unit $\mathrm{F} 1$, ranging from -24.41 to $-23.80 \mathrm{~m}$ NAP, yields rich faunas with a low diversity. The interval is characterised by high numbers of Ammonia parkinsoniana tepida, Elphidium albiumbilicatum, Elphidium williamsoni and Nonion germanicum except in the uppermost sample (see also Fig. 9). The assemblage has no modern analogue in the nordic seas. E. albiumbilicatum is typical of shallow brackish waters of the Baltic (Lutze, 1965), whereas both $A$. parkinsoniana tepida and $N$. germanicum are characteristic of the Wadden Sea intertidal flats (e.g., Van Voorthuysen, 1960; Haake, 1962). Only E. williamsoni is abundant in both areas. This species seems to be a good indicator of water depths because it lives close to the high-water level in sheltered parts of the Wadden Sea (e.g., Richter, 1967) and at very shallow depth in the lagoonal and estuarine parts of Kiel Bay (Lutze, 1965).

Both $A$. parkinsoniana tepida and E. albiumbilicatum are definitely associated with low salinities. The latter species is probably indicative of very brackish conditions since it flourishes at salinities as low as 6-9\%o (Lutze, 1965).

\section{Unit F2}

Unit $F 2$, ranging from -23.65 to $-17.80 \mathrm{~m}$ NAP, yields faunas with a lower number of individuals but more species than unit F1. The high abundances of Buccella frigida and Nonion depressulum are particularly characteristic here. The assemblage is no longer of brackish-water character: A. parkinsoniana tepida and E. albiumbilicatum are virtually absent. On the other hand, Quinqueloculina seminula s.1., a stenohaline species (Murray, 1971) is consistently present. The increase in salinity was probably coupled to an increase in water depth because $E$. williamsoni is only a subordinate element in the faunas.
The fairly common occurrence of E. lidoense in the lower sample also indicates a deeper-water environment.

Although the salinity may be comparable to that of the modern North Sea, open-marine conditions did not prevail. Species of the open sea (such as Ammonia beccarii and Elphidium gerthi) did occur, but were few and scarce. Another argument is the abundance of Nonion depressulum. This is considered a lagoonal rather than an inner shelf species, as supposed by Murray (1971), because it is characteristic of the Wadden Sea rather than the North Sea (Haake, 1962; Richter, 1967). Richter (1967) reported $N$. depressulum as characteristic of lowlying sandy tidal flats, close to the open sea. Data regarding its distribution in Holocene and Eemian sediments in the Netherlands suggest, however, that $N$. depressulum is best described as a lagoonal species that lives at or below the low-water level.

It is not clear how the abundance of Buccella frigida should be interpreted. The distribution of this taxon in the Eemian of the Netherlands suggests that its depth habitat lies between that of relatively deep-living species such as $E$. excavatum s.l., and that of shallow-living species such as $N$. germanicum. B. frigida is nowadays rare in the North Sea, the Wadden Sea and the Baltic. The reason is probably that temperatures are too high, because it is generally considered to be a boreo-arctic or arctic species (Konradi, 1976). The apparent preference of $B$. frigida for relatively low temperatures makes its cooccurrence with lusitanian species such as E. translucens remarkable. As an explanation, a very large seasonal contrast in temperature could be invoked. This suggestion arises from observations in NE Japan; Matoba (1970) reported that both B. frigida and Ammonia, which indicates relatively warm water, occur abundantly in shallow lagoonal bays where temperatures are high in summer (August: $25-29^{\circ} \mathrm{C}$ ) and much lower in winter (January: $\left.1-3^{\circ} \mathrm{C}\right)$.

The number of foraminifers decreases upwards and the upper two samples are almost barren. The low numbers are taken as an indication of repeated reworking of the sediments (cf. Uffenorde, 1982).

\section{Unit F3}

Unit $\mathrm{F} 3$, ranging from -15.80 to $-12.15 \mathrm{~m}$, comprises various faunas with a fairly high number of individuals. The differences with unit F2 are large. $A$. parkinsoniana tepida, Elphidium gunteri and Nonion germanicum are abundant and jointly comprise $50-90 \%$ of the fauna. A comparable fauna occurs today in the mud flats of the estuarine parts of the Wadden Sea (Van Voorthuysen, 1960; Haake, 1962; Richter, 1967).

Elphidium gunteri is especially abundant in the upper part of the unit. In contrast to the other species mentioned, the habitat of E. gunteri is restricted to the mud flats of the Wadden Sea. The change towards higher 
abundances might therefore be attributed to a shallowing of the environment.

\section{Unit F4}

Unit $F 4$, ranging from -12.15 to $-10.65 \mathrm{~m} \mathrm{NAP}$, is characterised by a fauna that almost exclusively consists of $N$. germanicum and E. gunteri. The number of individuals is low and the tests indicate evidence of dissolution.

The assemblage closely resembles the faunas that actually live on the mud flats in the estuarine parts of the Wadden Sea. Both Haake (1962) and Richter (1967) have shown, indeed, that there are systematic differences between the biocoenoses and thanatocoenoses of the Wadden Sea. In general, characteristic features of the thanatocoenoses are a higher proportion of Ammonia and a higher number of species. A specific feature of the thanatocoenoses of the mud flats is their much lower percentage of E. gunteri. These differences give the fauna of this unit a strong resemblance to a mudflat biocoenosis and that of the underlying unit a close similarity to a thanatocoenosis.

The change towards a more autochthonous signal implies a decrease of hydrodynamic energy. This is interpreted in this context as a shallowing of the environment.

\section{Appendix 3: diatoms from Amersfoort-1}

In unit D1 (-24.44 to $-24.22 \mathrm{~m}$ NAP), Grammatophora oceanica, Actinoptychus undulatus and Dimerogramma minor are the dominant diatoms. The preservation of these very robust diatom species is poor. Most of the diatoms are partly broken and dissolved. The flora is considered to be allochtonous since it consists of species characteristic of strongly varying environments. Epiphytic, epipsammic and planktonic species are found together in a single assemblage. Diatom floras from different niches in the basin were probably washed together in shallow-marine water at the margins of the basin between the icepushed ridges. The fossilised flora is therefore allochtonous. The presence of Grammatophora oceanica and Hyalodiscus scoticus, at the base of the marine succession in the Amersfoort-1 borehole, is not well understood. In the Amsterdam-Terminal borehole, as well as in other boreholes from the same basin, however, the species are found at exactly the same stratigraphical position, i.e. the base of the marine sequence in pollen zone E4a.

The interval of unit D2 ( -24.22 to $-23.87 \mathrm{~m} \mathrm{NAP})$ shows a dominance of the planktonic diatom Paralia (Melosira) sulcata, but epipsammic (Dimerogramma minor) and epiphytic species (Cocconeis disculoïdes) have also been preserved. Campylodiscus echeneis, Rhopalodia constricta and Glyphodesmis distans are present in low percentages in all samples. These species indicate a shallowmarine, near-shore environment. Some of these species live on seaweed. The diatom assemblage from this unit represents various biotopes in the basin and is allochtonous.

Unit D3 ( -23.72 to $-23.68 \mathrm{~m}$ NAP) consists of two samples, both poor in diatoms. Paralia sulcata is still the dominant species; most of its frustules are broken. In the lower sample, the epipsammic Dimerogramma minor and the epiphytic Cocconeis disculoides are found. Sedimentation probably occurred under similar environmental conditions as described for unit D2. Because of synsedimentary dissolution, only the most robust frustules of the diatom flora have been preserved.

Unit D4 is represented by a sample taken from a core $(-23.23 \mathrm{~m})$ and by a bailer sample $(-23.20 \mathrm{~m})$. In contrast to unit D3, Grammatophora oceanica is found here again in the diatom assemblage. In addition to this epiphytic species, epipsammic species are present. For the first time in the record, Stephanopyxis turris was found; it occurred in the stratified deposits of the AmsterdamTerminal borehole (Van Leeuwen et al., 2000 - this issue). The diatom assemblage is partly a result of the reworking of the older, organic deposits at the basin margin.

The samples from unit D5 ( -23.11 to $-22.61 \mathrm{~m}$ NAP) are rich in diatoms, most of which are lusitanian species. In this sandy environment, the percentages of epipsammic diatom species (Dimerogramma minor, Catenula adherens, Achnanthes delicatula and Opephora parva) are high, indicating. Some epiphytic species, such as Cocconeis scutellum and $C$. disculoïdes, are also present; they point to a vegetation of Zostera and/or algae. The assemblage suggests clear water with a depth of less than 10 m.

Unit D6 is represented by two bailer samples $(-22.55$ to -21.80 and -21.80 to $-20.80 \mathrm{~m}$ NAP). The coarse sands are very poor in diatoms. The presence of $R a-$ phoneis minutissima and Cymatosira belgica points to more open-marine conditions. 